\title{
Will Casuarina glauca Stress Resilience Be Maintained in the Face of Climate Change?
}

\author{
Tiago F. Jorge ${ }^{1} \mathbb{D}$, José C. Ramalho ${ }^{2,3} \mathbb{D}$, Saleh Alseekh ${ }^{4,5} \mathbb{D}$, Isabel P. Pais ${ }^{3,6}$, António E. Leitão ${ }^{2,3} \mathbb{D}$, \\ Ana P. Rodrigues ${ }^{2}\left(\mathbb{D}\right.$, Paula Scotti-Campos ${ }^{3,6}{ }^{(\mathbb{D}}$, Ana I. Ribeiro-Barros ${ }^{2,3} \mathbb{D}_{\text {, Alisdair R. Fernie }}^{4,5}$ \\ and Carla António $1, *,+\mathbb{D}$
}

check for updates

Citation: Jorge, T.F.; Ramalho, J.C.; Alseekh, S.; Pais, I.P.; Leitão, A.E.; Rodrigues, A.P.; Scotti-Campos, P.; Ribeiro-Barros, A.I.; Fernie, A.R.; António, C. Will Casuarina glauca Stress Resilience Be Maintained in the Face of Climate Change? Metabolites 2021, 11, 593. https://doi.org/ 10.3390/metabo11090593

Academic Editor:

Gabriele Capodaglio

Received: 10 August 2021

Accepted: 31 August 2021

Published: 2 September 2021

Publisher's Note: MDPI stays neutral with regard to jurisdictional claims in published maps and institutional affiliations.

Copyright: (c) 2021 by the authors. Licensee MDPI, Basel, Switzerland. This article is an open access article distributed under the terms and conditions of the Creative Commons Attribution (CC BY) license (https:// creativecommons.org/licenses/by/ $4.0 /)$
1 Plant Metabolomics Laboratory, Instituto de Tecnologia Química e Biológica António Xavier, Universidade Nova de Lisboa (ITQB NOVA), Avenida da República, 2780-157 Oeiras, Portugal; tiago.jorge89@gmail.com

2 Plant Stress \& Biodiversity Lab, Centro de Estudos Florestais (CEF), Instituto Superior de Agronomia (ISA), Universidade de Lisboa (ULisboa), Tapada da Ajuda, 1349-017 Lisboa and Quinta do Marquês, Portugal; cochichor@mail.telepac.pt (J.C.R.); antonioleitao@isa.ulisboa.pt (A.E.L.); anadr@isa.ulisboa.pt (A.P.R.); aribeiro@isa.ulisboa.pt (A.I.R.-B.)

3 GeoBioSciences, GeoTechnologies and GeoEngineering (GeoBioTec), Faculdade de Ciências e Tecnologia (FCT), Universidade NOVA de Lisboa (UNL), 2829-516 Monte de Caparica, Portugal; isabel.pais@iniav.pt (I.P.P.); paula.scotti@iniav.pt (P.S.-C.)

4 Central Metabolism Group, Max Planck Institute of Molecular Plant Physiology, 14476 Potsdam-Golm, Germany; alseekh@mpimp-golm.mpg.de (S.A.); fernie@mpimp-golm.mpg.de (A.R.F.)

5 Center of Plant Systems Biology and Biotechnology, 4000 Plovdiv, Bulgaria

6 Unidade de Investigação em Biotecnologia e Recursos Genéticos, Instituto Nacional de Investigação Agrária e Veterinária, I.P. (INIAV), 2784-505 Oeiras, Portugal

* Correspondence: plantmetabolomicslabpt@gmail.com

† Current address: Plant Metabolomics Lab Portugal, Centro de Estudos Florestais (CEF), Instituto Superior de Agronomia (ISA), Universidade de Lisboa (ULisboa), Tapada da Ajuda, 1349-017 Lisboa, Portugal.

Abstract: Actinorhizal plants have been regarded as promising species in the current climate change context due to their high tolerance to a multitude of abiotic stresses. While combined salt-heat stress effects have been studied in crop species, their impact on the model actinorhizal plant, Casuarina glauca, has not yet been fully addressed. The effect of single salt $(400 \mathrm{mM} \mathrm{NaCl})$ and heat (control at $26 / 22{ }^{\circ} \mathrm{C}$, supra optimal temperatures at $35 / 22{ }^{\circ} \mathrm{C}$ and $45 / 22{ }^{\circ} \mathrm{C}$ day/night) conditions on C. glauca branchlets was characterised at the physiological level, and stress-induced metabolite changes were characterised by mass spectrometry-based metabolomics. C. glauca could withstand single salt and heat conditions. However, the harshest stress condition $\left(400 \mathrm{mM} \mathrm{NaCl}, 45^{\circ} \mathrm{C}\right)$ revealed photosynthetic impairments due to mesophyll and membrane permeability limitations as well as major stress-specific differential responses in $\mathrm{C}$ and $\mathrm{N}$ metabolism. The increased activity of enzymatic ROS scavengers was, however, revealed to be sufficient to control the plant oxidative status. Although C. glauca could tolerate single salt and heat stresses, their negative interaction enhanced the effects of salt stress. Results demonstrated that C. glauca responses to combined salt-heat stress could be explained as a sum of the responses from each single applied stress.

Keywords: actinorhizal plants; Casuarina glauca; combined stress; heat stress; metabolomics; salt stress

\section{Introduction}

By the end of the 21st century, $\mathrm{CO}_{2}$ levels and global temperatures are expected to rise by $700 \mathrm{ppm}$ and $1.5^{\circ} \mathrm{C}$, respectively [1]. Consequently, higher surface temperatures, frequent heat waves and intense precipitation events are likely to occur around the globe. These (stress)-factors negatively affect plant growth and development and trigger highly complex adaptive responses initiated by stress perception, signal transduction and the activation of stress-related genes and metabolites [2,3]. Most studies to date have focused on plant responses to a single stress and as such, do not mimic the natural environmental conditions wherein a combination of stresses is known to occur [4]. Recent studies 
have, however, demonstrated that combined stresses cannot be regarded as a sum of the responses induced from each single stress. In these studies, stress combinations elicited specific physiological, biochemical and metabolic responses due to a cross-talk of synergistic or antagonistic effects that are controlled by opposing signalling pathways [5-9]. Combined exposure to salt and heat stress has been shown to provide both positive and negative interactions in physiological traits [4,10-12]. In wheat (Triticum aestivum $\mathrm{L}$. and Triticum durum Desf.), combined salt-heat stress promoted the uptake of toxic $\mathrm{Na}^{+}$ions from salt stress and enhanced the heat stress-induced transpiration rate [13]. In tomato (Solanum lycopersicum L.), combined salt-heat stress ameliorated the effects of salt stress through the accumulation of glycine betaine and trehalose (well-known osmolytes), which helped improve plant performance by mitigating both photosynthetic damages and overaccumulation of reactive oxygen species (ROS) [14]. Single salt and heat stresses are known to trigger common molecular responses in plants [15]. An excess of $\mathrm{Na}^{+}$ions in the soil can severely induce both osmotic and ionic stress within plant tissues leading to an impairment of the photosynthetic machinery and an accumulation of ROS that affect plant growth and metabolism [16,17]. Likewise, heat stress impairs the plant photosynthetic apparatus and metabolism due to a disruption of cell membrane fluidity that promotes overaccumulation of ROS and affects protein and enzyme stabilities $[18,19]$. Under single salt or heat stresses, plants were also reported to synthesize and accumulate osmolytes that play key roles in the regulation of osmotic potential and stabilization of biomolecules [20].

While the effects of a salt-heat stress combination have been mainly studied in crop species, their impact on ecologically important species has not yet been addressed. Actinorhizal plants are increasingly regarded as important species in the current climate change context $[21,22]$ due to their ability to tolerate harsh environmental conditions [23,24]. This group of perennial dicotyledonous angiosperms establish root-nodule symbiosis with the $\mathrm{N}$-fixation bacteria Frankia [24] and have a remarkable economic and ecological importance, often being used in the production of biomass and reclamation of degraded soils [25].

The model actinorhizal plant, Casuarina glauca Sieber (family Casuarinaceae), is native to Australia and widely distributed in areas where salt and heat stresses are likely to occur simultaneously (e.g., the Mediterranean, arid and semi-arid climates) [26,27]. The salt-stress tolerance of this species and the contribution of the symbiotic bacteria Frankia Thr strain have been thoroughly assessed at the physiological and biochemical levels [28-36]. These studies reported that, after exposing C. glauca Sieb. Ex Spreng nodulated $\left(\mathrm{NOD}^{+}\right)$and nonnodulated $\left(\mathrm{KNO}_{3}{ }^{+}\right)$plants up to $600 \mathrm{mM} \mathrm{NaCl}$, an early salt-stress exposure (i.e., $200 \mathrm{mM}$ $\mathrm{NaCl}$ ) impairs the plant-bacteria symbiotic association [30]. Moreover, C. glauca plants withstand increasing salt concentrations by maintaining a controlled oxidative environment inside the cells and performing osmotic adjustments that contribute to a nearly stable photosynthetic machinery up to $400 \mathrm{mM} \mathrm{NaCl}[28,32]$. These findings were supported by mass spectrometry (MS)-based proteomics studies that reported maintenance of the proteome stability at the highest salt-stress levels [36]. MS-based metabolomics studies revealed metabolite divergences in amino acid metabolism between $\mathrm{NOD}^{+}$and $\mathrm{KNO}_{3}{ }^{+}$ plants and suggested that a flavonoid-based secondary antioxidant system complements ascorbate-glutathione cycle components that support the maintenance of a stable oxidative environment within the cell [33,35].

Given the highly promising tolerance of $C$. glauca to abiotic stresses, the effects of both single and combined exposure to salt and heat stress were investigated in C. glauca branchlets through physiological and MS-based metabolomics analyses in order to (i) evaluate the impact of combined salt-heat stress in the photosynthetic functioning (ii) characterise stress-induced metabolite changes, and (iii) identify key physiological and metabolite cross-responses associated with combined salt-heat stress in this species. 


\section{Results}

\subsection{Phenotypic Analysis and Plant Water Relations}

The effect of a single exposure to salt or heat stress conditions did not lead to major phenotypic changes in C. glauca plants. However, a pronounced visual phenotypic effect was observed at the harshest stress condition $\left(400 \mathrm{mM} \mathrm{NaCl}, 45^{\circ} \mathrm{C}\right)$ (Figure 1a). The impact of temperature on RWC was observed only at $45^{\circ} \mathrm{C}$, when compared to the control temperature $\left(26^{\circ} \mathrm{C}\right)$ and without salt exposure (Figure $\left.1 \mathrm{~b}\right)$. High salt concentration $(400 \mathrm{mM} \mathrm{NaCl})$ significantly decreased RWC values for all temperatures. This decrease was more pronounced at $400 \mathrm{mM} \mathrm{NaCl}, 45^{\circ} \mathrm{C}$; even when RWC values were reduced only to $85 \%$.

(a)

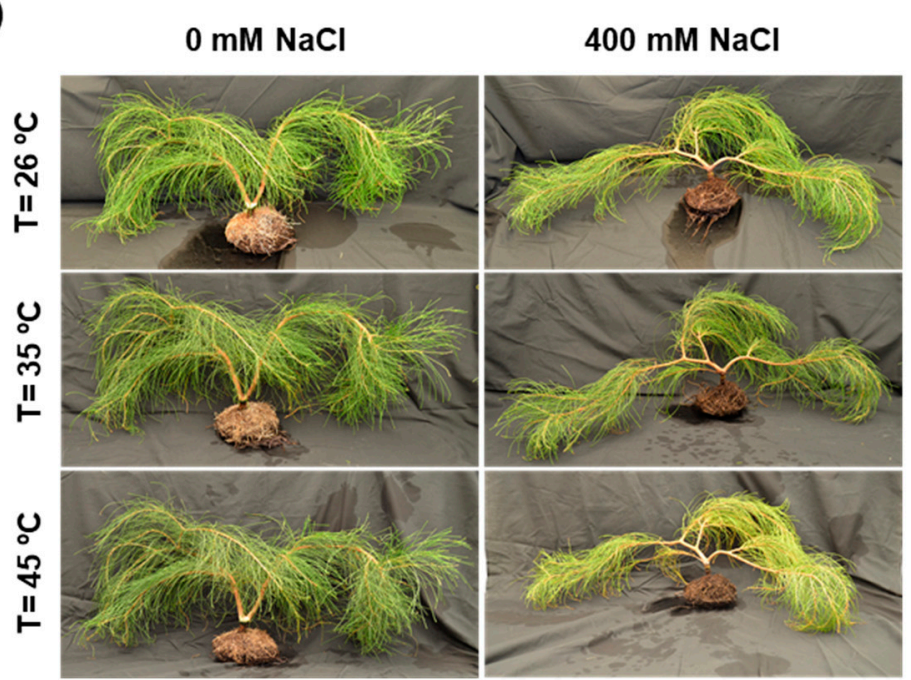

(b)

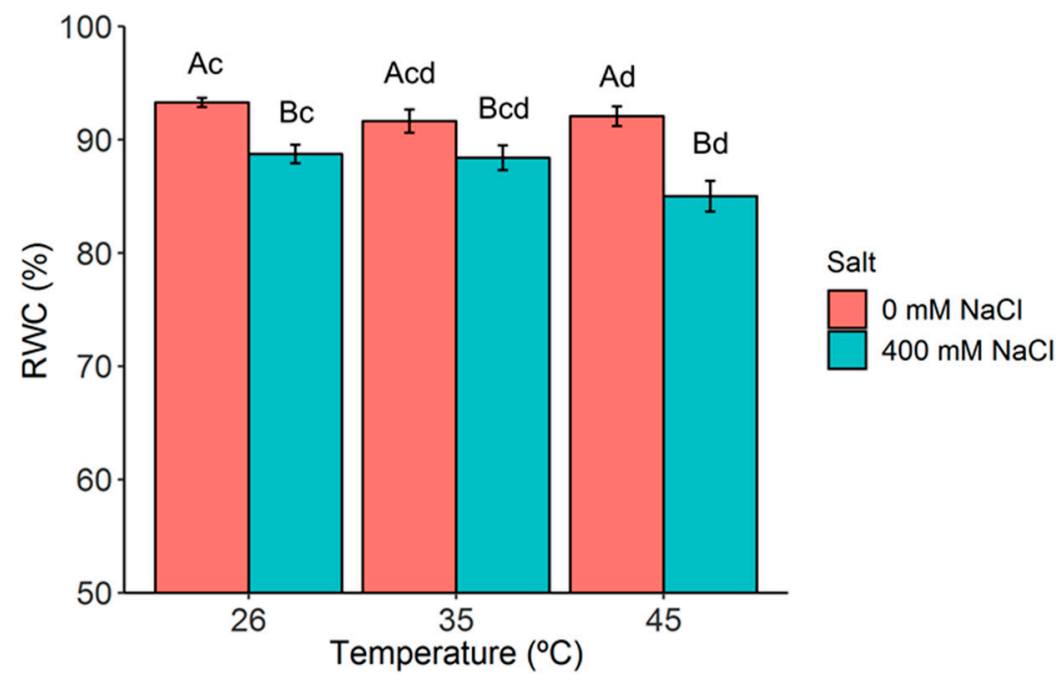

Figure 1. Evaluation of single salt, heat, and combined salt-heat stresses in C. glauca plants. (a) Visual evaluation of phenotypic changes in C. glauca plants under the single and combined exposure to salt $(0$ and $400 \mathrm{mM} \mathrm{NaCl})$ and temperature $\left(26,35\right.$ and $\left.45^{\circ} \mathrm{C}\right)$ conditions. (b) Variation of the relative water content (RWC, \%) in C. glauca branchlets under the single and combined exposure to salt $(0$ and $400 \mathrm{mM} \mathrm{NaCl})$ and temperature $\left(26,35\right.$ and $\left.45^{\circ} \mathrm{C}\right)$ conditions. Bars represent the mean values \pm SE from three to five independent measurements. Two-way ANOVA $(p<0.05)$ followed by Tukey's HSD test was performed for means comparison, and different letters express significant differences between $[\mathrm{NaCl}]$ for the same temperature $(\mathrm{A}, \mathrm{B})$ or between temperature for the same $[\mathrm{NaCl}](\mathrm{c}, \mathrm{d})$, with $\mathrm{A}$ and $\mathrm{c}$ representing the highest values. 


\subsection{Photosynthetic Gas Exchanges}

The net photosynthetic rate $\left(\mathrm{P}_{n}\right)$ was not reduced with increasing temperature imposition, even at $45^{\circ} \mathrm{C}$. In contrast, $\mathrm{P}_{\mathrm{n}}$ was significantly reduced under single salt conditions $\left(26^{\circ} \mathrm{C}\right)$, and was even more affected with the superimposition of heat, which led to negative values in plants exposed to $400 \mathrm{mM} \mathrm{NaCl}$ and $45^{\circ} \mathrm{C}$ (Figure 2a).

(a)

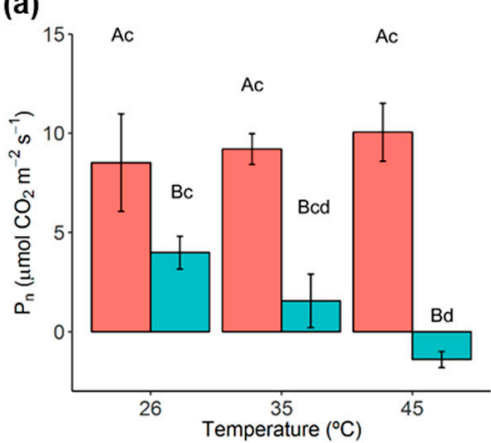

(c)

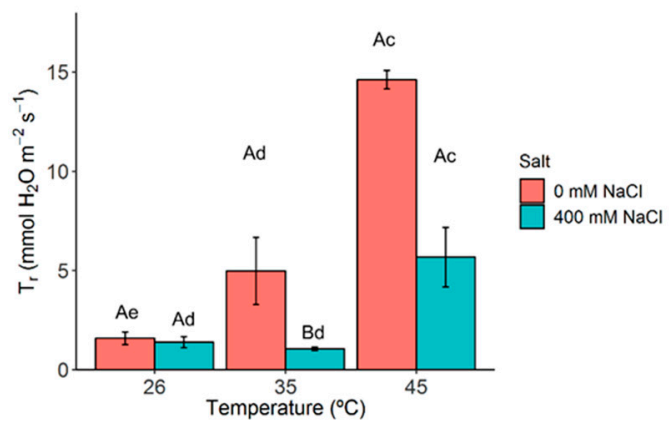

(e)
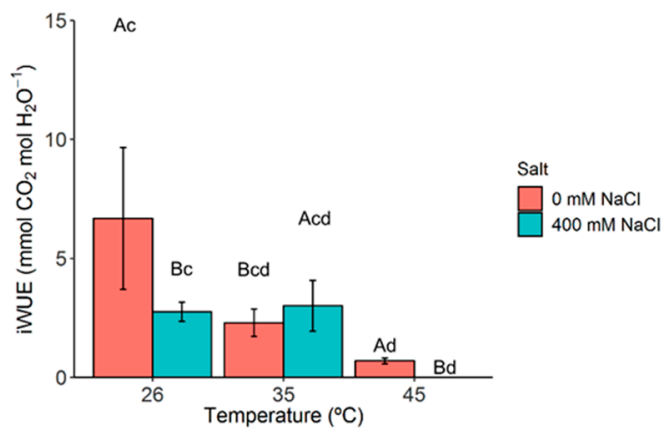

(b)

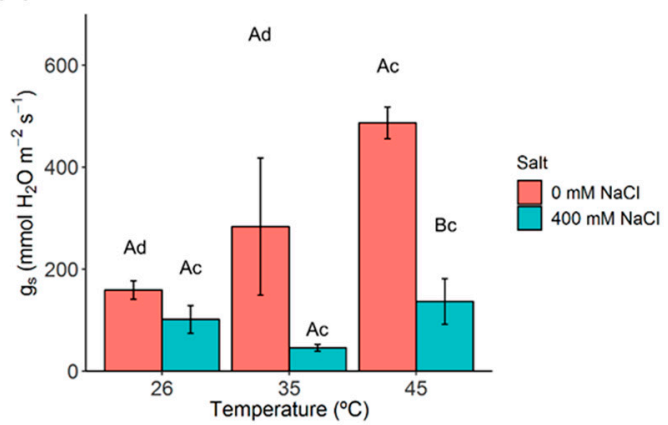

(d)

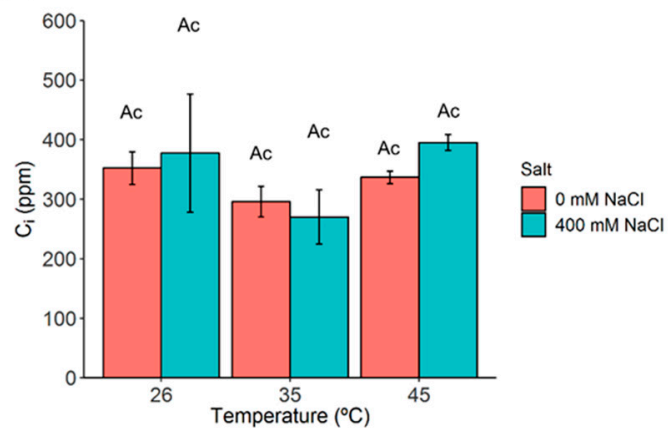

(f)

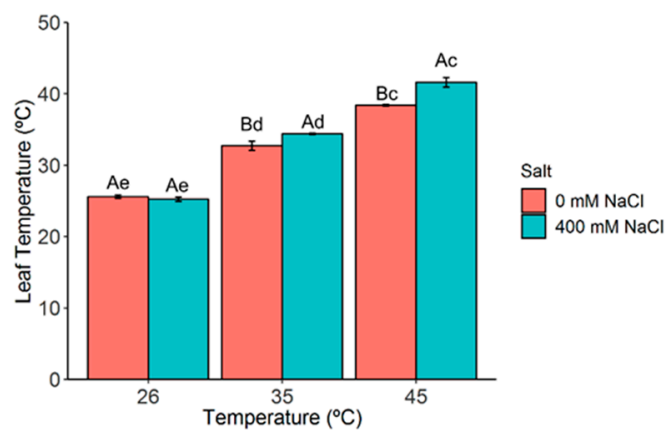

Figure 2. Analysis of gas exchange measurements in C. glauca branchlets under the single and combined exposure to salt $(0$ and $400 \mathrm{mM} \mathrm{NaCl})$ and temperature $\left(26,35\right.$ and $\left.45^{\circ} \mathrm{C}\right)$ conditions. (a) Net photosynthetic rate $\left(\mathrm{P}_{\mathrm{n}}\right)$. (b) Stomatal conductance to water vapour rate $\left(g_{s}\right)$. (c) Transpiration rate $(\mathrm{Tr})$. (d) Internal $\mathrm{CO}_{2}$ concentration $\left(\mathrm{C}_{\mathrm{i}}\right)$. (e) Instantaneous water use efficiency (iWUE). (f) Leaf temperature. Bars represent the mean values $\pm S E$ from three to five independent measurements. Two-way ANOVA $(p<0.05)$ followed by Tukey's HSD test was performed for means comparison and different letters express significant differences between $[\mathrm{NaCl}]$ for the same temperature $(\mathrm{A}, \mathrm{B})$ or between temperature for the same $[\mathrm{NaCl}](\mathrm{c}, \mathrm{d}, \mathrm{e})$ with $\mathrm{A}$ and c representing the highest values.

Single heat stress $\left(0 \mathrm{mM} \mathrm{NaCl}, 45^{\circ} \mathrm{C}\right)$ induced a significant increase of stomatal conductance to water vapour rate $\left(\mathrm{g}_{\mathrm{s}}\right)$ (Figure $2 \mathrm{~b}$ ). However, under both high temperatures and salt conditions ( 35 and $45^{\circ} \mathrm{C}, 400 \mathrm{mM} \mathrm{NaCl}$ ), significant differences emerged between salt treatments mostly due to the large $g_{s}$ increase in the $0 \mathrm{mM} \mathrm{NaCl}$ plants. Transpiration rate $(\mathrm{Tr})$ followed a pattern close to that of $\mathrm{g}_{\mathrm{s}}$, with significant increases under heat stress, while salt led to significant changes but only when combined with the highest temperatures (35 and $45^{\circ} \mathrm{C}$ ) (Figure $2 \mathrm{c}$ ). Internal $\mathrm{CO}_{2}$ concentration $\left(\mathrm{C}_{\mathrm{i}}\right)$ did not statistically change under 
all treatments (Figure 2d), suggesting that the observed reduction of $g_{s}$ in salt-exposed plants was not the main cause for the decline of $P_{n}$ in these same plants. Regarding the instantaneous water use efficiency (iWUE), single exposure of salt, and heat led to significant reductions. However, a stronger iWUE reduction was observed under the simultaneous presence of both treatments (Figure 2e).

Significant increases in leaf temperature were promoted mainly by the rise in temperature $\left(35\right.$ and $45^{\circ} \mathrm{C}$ ) as depicted from the similar patterns of 0 and $400 \mathrm{mM} \mathrm{NaCl}$ plants. The superimposition of salt led to significantly higher values of leaf temperature at 35 and $45^{\circ} \mathrm{C}$, likely related to the much lower $\mathrm{Tr}$ values in $400 \mathrm{mM} \mathrm{NaCl}$ plants as compared to $0 \mathrm{mM} \mathrm{NaCl}$ plants at those temperatures (Figure 2f).

\subsection{Chlorophyll a Fluorescence}

The impact of single and combined salt-heat stresses in the photosynthetic functioning was further evaluated through chlorophyll a fluorescence analysis (Table 1).

Table 1. Chlorophyll a fluorescence measurements C. glauca branchlets under the single and combined exposure to salt $(0$ and $400 \mathrm{mM} \mathrm{NaCl})$ and temperature $\left(26,35\right.$ and $45^{\circ} \mathrm{C}$ ) conditions. The parameters included: minimal fluorescence $\left(\mathrm{F}_{\mathrm{o}}\right)$, maximal photochemical efficiency of PSII $\left(\mathrm{F}_{\mathrm{v}} / \mathrm{F}_{\mathrm{m}}\right)$ (both measured under dark-adapted conditions), the estimate of the quantum yield of non-cyclic electron transport $\left(\mathrm{Y}_{(\mathrm{II})}=\Phi_{\mathrm{e}}\right)$, the quantum yield of regulated energy dissipation of PSII ( $\left.\mathrm{Y}_{(\mathrm{NPQ})}\right)$, the quantum yield of non-regulated energy dissipation (heat and fluorescence) dissipation of PSII ( $\left.\mathrm{Y}_{(\mathrm{NO})}\right)$, the photoprotective sustained thermal dissipation (NPQ), the non-photochemical quenching ( $\mathrm{q}_{\mathrm{N}}$ ), the photochemical quenching based on the concept of separated $\left(\mathrm{q}_{\mathrm{P}}\right)$ or interconnected $\left(\mathrm{q}_{\mathrm{L}}\right)$ antennae, the electron transport rate (ETR), the PSII photochemical efficiency under photosynthetic steady-state conditions $\left(\mathrm{F}_{\mathrm{v}}{ }^{\prime} / \mathrm{F}_{\mathrm{m}}{ }^{\prime}\right)$, the predictor of the rate constant of PSII inactivation $\left(\mathrm{F}_{\mathrm{s}} / \mathrm{F}_{\mathrm{m}}{ }^{\prime}\right)$, the chronic photoinhibition $\left(\mathrm{PI}_{\mathrm{Chr}}\right)$, the dynamic photoinhibition $\left(\mathrm{PI}_{\mathrm{Dyn}}\right)$ and the total photoinhibition (Total PI). Each value represents the mean \pm SE of three to five independent measurements. Two-way ANOVA $(p<0.05)$ followed by Tukey's HSD test was performed for means comparison and different letters express significant differences between $[\mathrm{NaCl}]$ for the same temperature $(\mathrm{A}, \mathrm{B})$ or between temperature for the same $[\mathrm{NaCl}](\mathrm{c}, \mathrm{d}, \mathrm{e})$ with $\mathrm{A}$ and $\mathrm{c}$ representing the highest values.

\begin{tabular}{|c|c|c|c|c|}
\hline \multirow{2}{*}{ Parameter } & \multirow{2}{*}[\mathrm{NaCl}]{} & \multicolumn{3}{|c|}{ Temperature } \\
\hline & & $26^{\circ} \mathrm{C}$ & $35^{\circ} \mathrm{C}$ & $45^{\circ} \mathrm{C}$ \\
\hline \multirow{2}{*}{$F_{0}$} & $0 \mathrm{mM}$ & $0.216 \pm 0.010 \mathrm{Ac}$ & $0.164 \pm 0.003 \mathrm{Ae}$ & $0.176 \pm 0.005 \mathrm{Ad}$ \\
\hline & $400 \mathrm{mM}$ & $0.201 \pm 0.005 \mathrm{Bc}$ & $0.170 \pm 0.004 \mathrm{Ad}$ & $0.201 \pm 0.010 \mathrm{Ad}$ \\
\hline \multirow{2}{*}{$\mathrm{F}_{\mathrm{v}} / \mathrm{F}_{\mathrm{m}}$} & $0 \mathrm{mM}$ & $0.772 \pm 0.008 \mathrm{Ac}$ & $0.818 \pm 0.004 \mathrm{Ac}$ & $0.786 \pm 0.007 \mathrm{Ac}$ \\
\hline & $400 \mathrm{mM}$ & $0.750 \pm 0.017 \mathrm{Ac}$ & $0.783 \pm 0.009 \mathrm{Ac}$ & $0.489 \pm 0.075 \mathrm{Bd}$ \\
\hline \multirow{2}{*}{$\begin{array}{l}Y_{(I I)}= \\
\emptyset_{e}\end{array}$} & $0 \mathrm{mM}$ & $0.533 \pm 0.029 \mathrm{Ac}$ & $0.456 \pm 0.022 \mathrm{Ac}$ & $0.365 \pm 0.018 \mathrm{Ad}$ \\
\hline & $400 \mathrm{mM}$ & $0.414 \pm 0.034 \mathrm{Bc}$ & $0.376 \pm 0.033 \mathrm{Bc}$ & $0.159 \pm 0.043 \mathrm{Bd}$ \\
\hline \multirow{2}{*}{$\mathrm{Y}_{(\mathrm{NPQ})}$} & $0 \mathrm{mM}$ & $0.108 \pm 0.010 \mathrm{Bd}$ & $0.190 \pm 0.019 \mathrm{Ad}$ & $0.254 \pm 0.013 \mathrm{Ac}$ \\
\hline & $400 \mathrm{mM}$ & $0.252 \pm 0.016 \mathrm{Ac}$ & $0.285 \pm 0.040 \mathrm{Ac}$ & $0.217 \pm 0.067 \mathrm{Ac}$ \\
\hline \multirow{2}{*}{$Y_{(N O)}$} & $0 \mathrm{mM}$ & $0.359 \pm 0.027 \mathrm{Ac}$ & $0.370 \pm 0.026 \mathrm{Ac}$ & $0.381 \pm 0.016 \mathrm{Bc}$ \\
\hline & $400 \mathrm{mM}$ & $0.334 \pm 0.022 \mathrm{Ad}$ & $0.339 \pm 0.012 \mathrm{Ad}$ & $0.623 \pm 0.106 \mathrm{Ac}$ \\
\hline \multirow{2}{*}{ NPQ } & $0 \mathrm{mM}$ & $0.322 \pm 0.035 \mathrm{Bd}$ & $0.543 \pm 0.061$ Acd & $0.670 \pm 0.049 \mathrm{Ac}$ \\
\hline & $400 \mathrm{mM}$ & $0.768 \pm 0.047 \mathrm{Ac}$ & $0.853 \pm 0.137 \mathrm{Ac}$ & $0.439 \pm 0.181 \mathrm{Ad}$ \\
\hline \multirow{2}{*}{$\mathrm{q}_{\mathrm{N}}$} & $0 \mathrm{mM}$ & $0.329 \pm 0.018 \mathrm{Bd}$ & $0.490 \pm 0.031 \mathrm{Ac}$ & $0.529 \pm 0.018 \mathrm{Ac}$ \\
\hline & $400 \mathrm{mM}$ & $0.556 \pm 0.018 \mathrm{Ac}$ & $0.597 \pm 0.044 \mathrm{Ac}$ & $0.534 \pm 0.069 \mathrm{Ac}$ \\
\hline \multirow{2}{*}{ qP } & $0 \mathrm{mM}$ & $0.778 \pm 0.027 \mathrm{Ac}$ & $0.714 \pm 0.017 \mathrm{Ac}$ & $0.590 \pm 0.024 \mathrm{Ad}$ \\
\hline & $400 \mathrm{mM}$ & $0.686 \pm 0.047 \mathrm{Bc}$ & $0.656 \pm 0.035 \mathrm{Bc}$ & $0.477 \pm 0.045 \mathrm{Bd}$ \\
\hline \multirow{2}{*}{$\mathrm{q}_{\mathrm{L}}$} & $0 \mathrm{mM}$ & $0.549 \pm 0.032 \mathrm{Ac}$ & $0.475 \pm 0.019$ Acd & $0.356 \pm 0.021 \mathrm{Ad}$ \\
\hline & $400 \mathrm{mM}$ & $0.500 \pm 0.045 \mathrm{Ac}$ & $0.451 \pm 0.030 \mathrm{Acd}$ & $0.380 \pm 0.029 \mathrm{Ad}$ \\
\hline \multirow{2}{*}{ ETR } & $0 \mathrm{mM}$ & $114.2 \pm 6.3 \mathrm{Ac}$ & $97.7 \pm 4.7$ Ac & $78.1 \pm 3.9$ Ac \\
\hline & $400 \mathrm{mM}$ & $88.7 \pm 7.3 \mathrm{Bc}$ & $80.6 \pm 7.1 \mathrm{Ac}$ & $34.1 \pm 9.1 \mathrm{Ad}$ \\
\hline \multirow{2}{*}{$\mathrm{F}_{\mathrm{v}}{ }^{\prime} / \mathrm{F}_{\mathrm{m}}{ }^{\prime}$} & $0 \mathrm{mM}$ & $0.679 \pm 0.016 \mathrm{Ac}$ & $0.638 \pm 0.021 \mathrm{Ac}$ & $0.618 \pm 0.008 \mathrm{Ac}$ \\
\hline & $400 \mathrm{mM}$ & $0.591 \pm 0.019 \mathrm{Bc}$ & $0.571 \pm 0.025 \mathrm{Ac}$ & $0.319 \pm 0.065 \mathrm{Bd}$ \\
\hline
\end{tabular}


Table 1. Cont.

\begin{tabular}{|c|c|c|c|c|}
\hline \multirow{2}{*}{ Parameter } & \multirow{2}{*}[\mathrm{NaCl}]{} & \multicolumn{3}{|c|}{ Temperature } \\
\hline & & $26^{\circ} \mathrm{C}$ & $35^{\circ} \mathrm{C}$ & $45^{\circ} \mathrm{C}$ \\
\hline \multirow{2}{*}{$\mathrm{F}_{\mathrm{s}} / \mathrm{F}_{\mathrm{m}}{ }^{\prime}$} & $0 \mathrm{mM}$ & $0.467 \pm 0.029 \mathrm{Bc}$ & $0.544 \pm 0.022 \mathrm{Ac}$ & $0.635 \pm 0.018 \mathrm{Ac}$ \\
\hline & $400 \mathrm{mM}$ & $0.586 \pm 0.034 \mathrm{Ad}$ & $0.624 \pm 0.033 \mathrm{Acd}$ & $0.841 \pm 0.043 \mathrm{Ac}$ \\
\hline \multirow{2}{*}{$\mathrm{PI}_{\mathrm{Chr}}$} & $0 \mathrm{mM}$ & $6.92 \pm 0.77 \mathrm{Ac}$ & $1.55 \pm 0.59 \mathrm{Ac}$ & $5.38 \pm 0.84 \mathrm{Bc}$ \\
\hline & $400 \mathrm{mM}$ & $8.91 \pm 1.34 \mathrm{Ad}$ & $5.76 \pm 1.44 \mathrm{Ad}$ & $41.2 \pm 13.8 \mathrm{Ac}$ \\
\hline \multirow{2}{*}{$\mathbf{P I}_{\text {Dyn }}$} & $0 \mathrm{mM}$ & $11.4 \pm 1.3 \mathrm{Bd}$ & $21.7 \pm 2.6 \mathrm{Bc}$ & $20.3 \pm 1.4 \mathrm{Bcd}$ \\
\hline & $400 \mathrm{mM}$ & $20.0 \pm 1.4 \mathrm{Ad}$ & $25.5 \pm 1.8 \mathrm{Ac}$ & $20.4 \pm 7.4$ Acd \\
\hline \multirow{2}{*}{ Total PI } & $0 \mathrm{mM}$ & $18.3 \pm 1.9 \mathrm{Bc}$ & $23.3 \pm 2.5 \mathrm{Ac}$ & $25.7 \pm 0.9 \mathrm{Bc}$ \\
\hline & $400 \mathrm{mM}$ & $28.9 \pm 2.3 \mathrm{Ad}$ & $31.3 \pm 3.0 \mathrm{Ad}$ & $61.6 \pm 7.8 \mathrm{Ac}$ \\
\hline
\end{tabular}

The maximal photochemical efficiency of PSII $\left(\mathrm{F}_{\mathrm{v}} / \mathrm{F}_{\mathrm{m}}\right)$ was significantly affected only under the harshest stress condition $\left(400 \mathrm{mM} \mathrm{NaCl}, 45^{\circ} \mathrm{C}\right)$. The estimate of the quantum yield of non-cyclic electron transport $\left(\mathrm{Y}_{(\mathrm{II})}\right)$ and the actual PSII photochemical efficiency $\left(\mathrm{F}_{\mathrm{v}}{ }^{\prime} / \mathrm{F}_{\mathrm{m}}{ }^{\prime}\right)$ showed similar patterns of variation and decreased under both single stresses. This reduction was clearly stronger at $400 \mathrm{mM} \mathrm{NaCl}, 45^{\circ} \mathrm{C}$. The quantum yield of regulated energy dissipation of PSII $\left(\mathrm{Y}_{(\mathrm{NPQ})}\right)$ significantly increased under salt conditions but only at $26^{\circ} \mathrm{C}$. Increasing temperatures also significantly increased $Y_{(\mathrm{NPQ})}$ in the $400 \mathrm{mM} \mathrm{NaCl}$ plants. Consequently, $\mathrm{Y}_{(\mathrm{NPQ})}$ significantly increased at $400 \mathrm{mM} \mathrm{NaCl}, 45^{\circ} \mathrm{C}$. The quantum yield of non-regulated energy dissipation of PSII $\left(\mathrm{Y}_{(\mathrm{NO})}\right)$ significantly increased under both single stresses, and consequently, strongly increased at $400 \mathrm{mM} \mathrm{NaCl}, 45^{\circ} \mathrm{C}$. The photochemical quenching based on the concept of separated $\left(\mathrm{q}_{\mathrm{P}}\right)$ antennae showed a similar pattern to that observed for $\mathrm{Y}_{(\mathrm{II})}, \mathrm{F}_{\mathrm{v}}{ }^{\prime} / \mathrm{F}_{\mathrm{m}}{ }^{\prime}$ with a statistically significant reduction at $400 \mathrm{mM} \mathrm{NaCl}, 45^{\circ} \mathrm{C}$. The total photoinhibition ( $\left.\mathrm{PI}_{\mathrm{Tot}}\right)$ significantly increased under both single stresses, but showed the highest modifications at $400 \mathrm{mM} \mathrm{NaCl}, 45^{\circ} \mathrm{C}$. Keeping in mind that Total PI is the sum of the chronic $\left(\mathrm{PI}_{\mathrm{Chr}}\right)$ and dynamic $\left(\mathrm{PI}_{\text {Dyn }}\right)$ photoinhibitions it is highly relevant that the strong rise in Total PI reported at this condition was due almost entirely to a large increase in $\mathrm{PI}_{\mathrm{Chr}}$.

\subsection{Photosynthetic Pigments}

Absolute levels for several photoprotective xanthophyll pigments, the de-epoxidation state (DEPS), and antioxidant carotenoids were next measured in C. glauca branchlets (Tables 2 and S1). The levels of the xanthophyll cycle pigment violaxanthin (Viol) significantly decreased upon single salt stress with the concomitant synthesis of antheraxanthin (Ant) and zeaxanthin (Zea), which increased (also under heat conditions). As for the photoprotective (dissipative) Ant and Zea, the highest increases were observed under the harshest stress condition $\left(400 \mathrm{mM} \mathrm{NaCl}, 45^{\circ} \mathrm{C}\right)$. The de-epoxidation state (DEPS) was significantly increased by both single stresses, but particularly when they were combined. Lutein levels significantly decreased under salt conditions but significantly increased due to heat, without apparent interaction of these stress conditions. The levels of $\beta$-Carotene significantly decreased under salt stress conditions at $35^{\circ} \mathrm{C}$, whereas at higher temperatures $\left(35\right.$ and $45^{\circ} \mathrm{C}$ ) and $0 \mathrm{mM} \mathrm{NaCl}$, its levels significantly increased. The harshest stress condition led to a significant increase of $\beta$-Carotene in comparison with control conditions $\left(0 \mathrm{mM} \mathrm{NaCl}, 26^{\circ} \mathrm{C}\right)$. 
Table 2. Photosynthetic pigments in C. glauca branchlets under the single and combined exposure to salt $(0$ and $400 \mathrm{mM} \mathrm{NaCl})$ and temperature $\left(26,35\right.$ and $\left.45^{\circ} \mathrm{C}\right)$ conditions. The de-epoxidation state (DEPS) was determined as DEPS $=[($ Zeaxanthin $($ Zea $)+0.5 \times$ Antheraxanthin $($ Ant $)) /($ Violaxanthin $($ Viol $)+$ Ant + Zea $)]$. Each value represents the mean \pm SE of three to five independent measurements. Two-way ANOVA $(p<0.05)$ followed by Tukey's HSD test was for performed for means comparison and different letters express significant differences between [ $\mathrm{NaCl}]$ for the same temperature $(\mathrm{A}, \mathrm{B})$ or between temperature for the same $[\mathrm{NaCl}](\mathrm{c}, \mathrm{d})$ with $\mathrm{A}$ and $\mathrm{c}$ representing the highest values.

\begin{tabular}{|c|c|c|c|c|}
\hline \multirow{2}{*}{$\begin{array}{c}\text { Pigments } \\
\left(\mathrm{mg} \mathrm{g}^{-1} \mathrm{DW}\right)\end{array}$} & \multirow{2}{*}[\mathrm{NaCl}]{} & \multicolumn{3}{|c|}{ Temperature } \\
\hline & & $26^{\circ} \mathrm{C}$ & $35^{\circ} \mathrm{C}$ & $45^{\circ} \mathrm{C}$ \\
\hline \multirow{2}{*}{ Neoxanthin (Neo) } & $0 \mathrm{mM}$ & $0.101 \pm 0.006 \mathrm{Ac}$ & $0.121 \pm 0.014 \mathrm{Ac}$ & $0.112 \pm 0.003 \mathrm{Ac}$ \\
\hline & $400 \mathrm{mM}$ & $0.058 \pm 0.004 \mathrm{Bc}$ & $0.061 \pm 0.006 \mathrm{Bc}$ & $0.069 \pm 0.007 \mathrm{Bc}$ \\
\hline \multirow{2}{*}{ Violaxanthin (Viol) } & $0 \mathrm{mM}$ & $0.116 \pm 0.008 \mathrm{Ac}$ & $0.120 \pm 0.014 \mathrm{Ac}$ & $0.105 \pm 0.005 \mathrm{Ac}$ \\
\hline & $400 \mathrm{mM}$ & $0.067 \pm 0.003 \mathrm{Bc}$ & $0.051 \pm 0.009 \mathrm{Bc}$ & $0.042 \pm 0.004 \mathrm{Bc}$ \\
\hline \multirow{2}{*}{ Anteraxanthin (Ant) } & $0 \mathrm{mM}$ & $0.004 \pm 0.001 \mathrm{Ad}$ & $0.005 \pm 0.000 \mathrm{Ad}$ & $0.013 \pm 0.001 \mathrm{Bc}$ \\
\hline & $400 \mathrm{mM}$ & $0.006 \pm 0.000 \mathrm{Ad}$ & $0.009 \pm 0.001 \mathrm{Ad}$ & $0.022 \pm 0.002 \mathrm{Ac}$ \\
\hline \multirow{2}{*}{ Zeaxanthin (Zea) } & $0 \mathrm{mM}$ & $0.000 \pm 0.000 \mathrm{Bd}$ & $0.002 \pm 0.001 \mathrm{Bd}$ & $0.011 \pm 0.003 \mathrm{Bc}$ \\
\hline & $400 \mathrm{mM}$ & $0.003 \pm 0.000 \mathrm{Ad}$ & $0.015 \pm 0.005 \mathrm{Ad}$ & $0.035 \pm 0.007 \mathrm{Ac}$ \\
\hline \multirow{2}{*}{ Viol+Ant+Zea } & $0 \mathrm{mM}$ & $0.120 \pm 0.008 \mathrm{Ac}$ & $0.126 \pm 0.012 \mathrm{Ac}$ & $0.129 \pm 0.002 \mathrm{Ac}$ \\
\hline & $400 \mathrm{mM}$ & $0.075 \pm 0.003 \mathrm{Bc}$ & $0.075 \pm 0.004 \mathrm{Bc}$ & $0.099 \pm 0.011 \mathrm{Bc}$ \\
\hline \multirow{2}{*}{ DEPS } & $0 \mathrm{mM}$ & $0.018 \pm 0.002 \mathrm{Ac}$ & $0.046 \pm 0.021 \mathrm{Bc}$ & $0.139 \pm 0.023 \mathrm{Bc}$ \\
\hline & $400 \mathrm{mM}$ & $0.070 \pm 0.005 \mathrm{Ad}$ & $0.282 \pm 0.077 \mathrm{Ad}$ & $0.442 \pm 0.034 \mathrm{Ac}$ \\
\hline \multirow{2}{*}{ Lutein } & $0 \mathrm{mM}$ & $0.257 \pm 0.018 \mathrm{Ad}$ & $0.338 \pm 0.037$ Acd & $0.367 \pm 0.008 \mathrm{Ac}$ \\
\hline & $400 \mathrm{mM}$ & $0.174 \pm 0.011 \mathrm{Bd}$ & $0.196 \pm 0.015 \mathrm{Bcd}$ & $0.245 \pm 0.023 \mathrm{Bc}$ \\
\hline \multirow{2}{*}{$\alpha$-Carotene } & $0 \mathrm{mM}$ & $0.019 \pm 0.002 \mathrm{Ad}$ & $0.054 \pm 0.001 \mathrm{Ac}$ & $0.050 \pm 0.004 \mathrm{Ac}$ \\
\hline & $400 \mathrm{mM}$ & $0.032 \pm 0.005 \mathrm{Ad}$ & $0.050 \pm 0.010 \mathrm{Ac}$ & $0.055 \pm 0.005 \mathrm{Ac}$ \\
\hline \multirow{2}{*}{$\beta$-Carotene } & $0 \mathrm{mM}$ & $0.007 \pm 0.001 \mathrm{Ad}$ & $0.020 \pm 0.002 \mathrm{Ac}$ & $0.017 \pm 0.001 \mathrm{Ac}$ \\
\hline & $400 \mathrm{mM}$ & $0.007 \pm 0.001 \mathrm{Ac}$ & $0.011 \pm 0.002 \mathrm{Bc}$ & $0.013 \pm 0.002 \mathrm{Ac}$ \\
\hline
\end{tabular}

\subsection{Ribulose-1,5-Biphosphate Carboxylase/Oxygenase (RuBisCO) Activity and Activation State}

The initial activity of RuBisCO was not significantly impacted by both single stresses (Figure 3a). Notably, despite the total activity of RuBisCO did not significantly increase at $35{ }^{\circ} \mathrm{C}$ (Figure $3 \mathrm{~b}$ ), a significant reduction in the activation status in the $0 \mathrm{mM} \mathrm{NaCl}$ plants at this temperature was observed (Figure 3c). Indeed, only at the harshest stress condition $\left(400 \mathrm{mM} \mathrm{NaCl}, 45^{\circ} \mathrm{C}\right.$ ) were clear reductions in both activities observed. However, even under these conditions, the activation state remained unaltered.

\subsection{Membrane Permeability and Lipid Peroxidation}

Membrane permeability and lipid peroxidation were assessed in C. glauca branchlets through electrolyte leakage and malonyldialdehyde (MDA) analyses, respectively. The percentage of electrolyte leakage significantly increased under salt conditions (Figure 4a). The MDA content did not change significantly under any salt or temperature treatment (Figure 4b).

\subsection{Lipid Analyses}

Total fatty acid (TFA) content, individual fatty acid (FA) composition, and the unsaturation (DBI) of total lipids were measured in C. glauca branchlets (Table 3). Only those demonstrated to significantly change in at least one condition are described. 
(a)

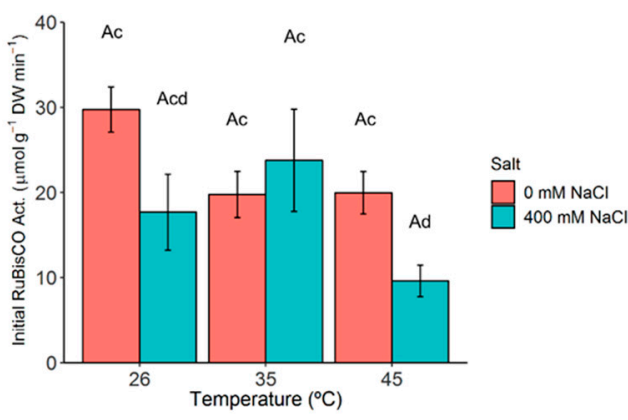

(b)

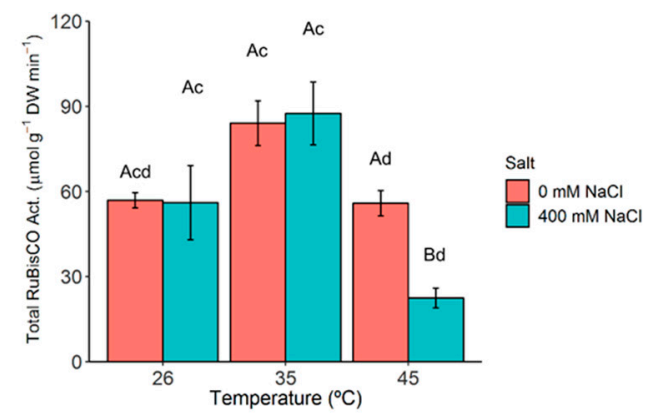

(c)

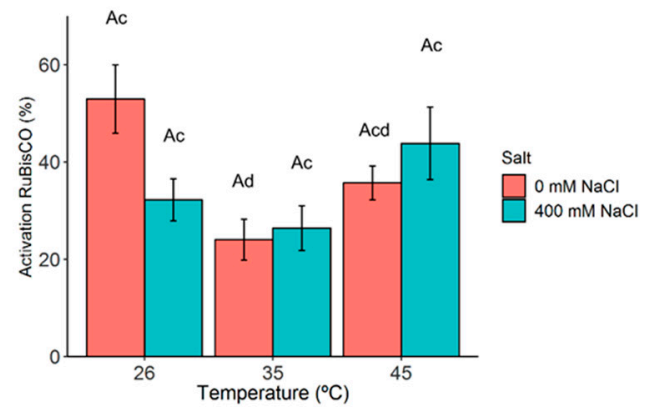

Figure 3. Variation of the ribulose-1,5-biphosphate carboxylase/oxygenase (RuBisCO) activity and activation state in C. glauca branchlets under the single and combined exposure to salt $(0$ and $400 \mathrm{mM} \mathrm{NaCl})$ and temperature $\left(26,35\right.$ and $\left.45^{\circ} \mathrm{C}\right)$ conditions. (a) Initial activity. (b) Total activity. (c) Activation state. Bars represent the mean values \pm SE from three to five independent measurements. Two-way ANOVA $(p<0.05)$ followed by Tukey's HSD test was performed for means comparison and different letters express significant differences between $[\mathrm{NaCl}]$ for the same temperature $(\mathrm{A}, \mathrm{B})$ or between temperature for the same $[\mathrm{NaCl}](\mathrm{c}, \mathrm{d})$ with $\mathrm{A}$ and c representing the highest values.

(a)

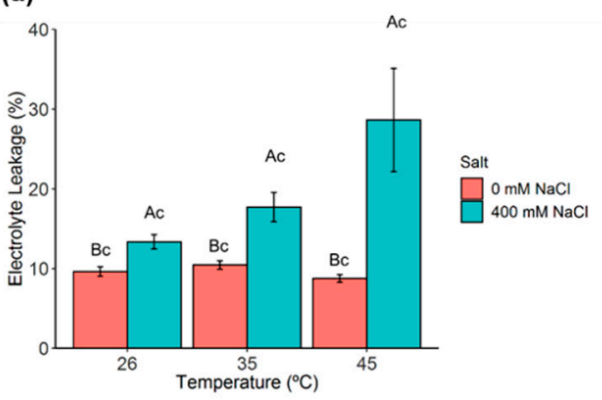

(b)

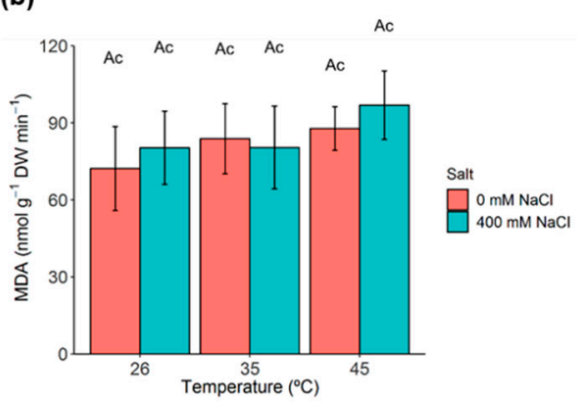

Figure 4. Membrane permeability and lipid peroxidation in C. glauca branchlets under the single and combined exposure to salt $(0$ and $400 \mathrm{mM} \mathrm{NaCl})$ and temperature $\left(26,35\right.$ and $\left.45^{\circ} \mathrm{C}\right)$ conditions. (a) Electrolyte leakage. (b) Malonyldialdehyde (MDA) content. Bars represent the mean values $\pm \mathrm{SE}$ from three to five independent measurements. Two-way ANOVA $(p<0.05)$ followed by Tukey's HSD test was performed for means comparison, and different letters express significant differences between $[\mathrm{NaCl}]$ for the same temperature $(\mathrm{A}, \mathrm{B})$ or between temperature for the same $[\mathrm{NaCl}](\mathrm{c})$ with $\mathrm{A}$ and $\mathrm{c}$ representing the highest values. 
Table 3. Total fatty acids (TFA, $\mathrm{mg} \mathrm{g}^{-1} \mathrm{DW}$ ), fatty acid composition (mol\%) and unsaturation (DBI) of $\mathrm{C}$. glauca branchlets under the single and combined exposure to salt $(0$ and $400 \mathrm{mM} \mathrm{NaCl})$ and temperature $\left(26,35\right.$ and $\left.45{ }^{\circ} \mathrm{C}\right)$ conditions. C18:3-linolenic acid. C18:2-linoleic acid. C16:0-palmitic acid. C18:1-oleic acid. C18:0-stearic acid. C16:1-hexadecenoic acid and less representative (Less Rep) fatty acids (i.e., the sum of less abundant FAs, namely C15:0-pentadecanoic acid, C14:0-myristic acid and C14:1-myristoleic acid $)$. DBI $=[(\%$ monoenes $+2 x \%$ dienes $+3 x \%$ trienes $) / \%$ saturated FAs $]$. Each value represents the mean $\pm \mathrm{SE}$ of three to five independent measurements. Two-way ANOVA $(p<0.05)$ followed by Tukey's HSD test was performed for means comparison, and different letters express significant differences between $[\mathrm{NaCl}]$ for the same temperature $(\mathrm{A}, \mathrm{B})$ or between temperature for the same $[\mathrm{NaCl}](\mathrm{c}, \mathrm{d})$ with $\mathrm{A}$ and $\mathrm{c}$ representing the highest values.

\begin{tabular}{|c|c|c|c|c|}
\hline \multirow{2}{*}{ Parameter } & \multirow{2}{*}[\mathrm{NaCl}]{} & \multicolumn{3}{|c|}{ Temperature $\left({ }^{\circ} \mathrm{C}\right)$} \\
\hline & & $26^{\circ} \mathrm{C}$ & $35^{\circ} \mathrm{C}$ & $45^{\circ} \mathrm{C}$ \\
\hline \multirow{2}{*}{ TFA (mg g $\left.{ }^{-1} \mathrm{DW}\right)$} & $0 \mathrm{mM}$ & $13.65 \pm 1.50 \mathrm{Ac}$ & $12.80 \pm 1.17 \mathrm{Ac}$ & $12.26 \pm 0.34 \mathrm{Ac}$ \\
\hline & $400 \mathrm{mM}$ & $8.10 \pm 1.40 \mathrm{Bc}$ & $7.94 \pm 0.53 \mathrm{Bc}$ & $6.80 \pm 0.65 \mathrm{Bc}$ \\
\hline \multirow{2}{*}{ C18:3 (mol\%) } & $0 \mathrm{mM}$ & $41.52 \pm 0.27 \mathrm{Ac}$ & $35.75 \pm 1.90 \mathrm{Ac}$ & $37.05 \pm 0.41 \mathrm{Ac}$ \\
\hline & $400 \mathrm{mM}$ & $33.82 \pm 2.44 \mathrm{Bc}$ & $34.72 \pm 1.01 \mathrm{Ac}$ & $24.53 \pm 2.43 \mathrm{Bd}$ \\
\hline \multirow{2}{*}{ C18:2 (mol\%) } & $0 \mathrm{mM}$ & $19.51 \pm 0.33 \mathrm{Bd}$ & $22.50 \pm 1.03 \mathrm{Ac}$ & $21.93 \pm 0.60 \mathrm{Bcd}$ \\
\hline & $400 \mathrm{mM}$ & $22.94 \pm 0.55 \mathrm{Ac}$ & $24.15 \pm 0.44 \mathrm{Ac}$ & $23.87 \pm 1.35 \mathrm{Ac}$ \\
\hline \multirow{2}{*}{ C18:1 (mol\%) } & $0 \mathrm{mM}$ & $5.73 \pm 0.08 \mathrm{Ad}$ & $7.35 \pm 0.26$ Acd & $7.66 \pm 0.24 \mathrm{Bc}$ \\
\hline & $400 \mathrm{mM}$ & $6.06 \pm 0.76 \mathrm{Ad}$ & $6.28 \pm 0.83$ Acd & $8.16 \pm 0.56 \mathrm{Ac}$ \\
\hline \multirow{2}{*}{ C18:0 (mol\%) } & $0 \mathrm{mM}$ & $2.65 \pm 0.21 \mathrm{Ac}$ & $2.64 \pm 0.24 \mathrm{Ac}$ & $2.00 \pm 0.19 \mathrm{Ac}$ \\
\hline & $400 \mathrm{mM}$ & $2.92 \pm 0.27 \mathrm{Ac}$ & $2.89 \pm 0.30 \mathrm{Ac}$ & $3.25 \pm 0.42 \mathrm{Ac}$ \\
\hline \multirow{2}{*}{ C16:1 (mol\%) } & $0 \mathrm{mM}$ & $3.68 \pm 0.23 \mathrm{Ac}$ & $3.39 \pm 0.40 \mathrm{Ac}$ & $3.92 \pm 0.12 \mathrm{Ac}$ \\
\hline & $400 \mathrm{mM}$ & $3.76 \pm 0.23 \mathrm{Ac}$ & $3.17 \pm 0.03 \mathrm{Ac}$ & $3.27 \pm 0.28 \mathrm{Ac}$ \\
\hline \multirow{2}{*}{ C16:0 (mol\%) } & $0 \mathrm{mM}$ & $25.67 \pm 0.68 \mathrm{Ac}$ & $27.12 \pm 2.35 \mathrm{Ac}$ & $26.30 \pm 0.80 \mathrm{Bc}$ \\
\hline & $400 \mathrm{mM}$ & $28.36 \pm 1.60 \mathrm{Acd}$ & $26.88 \pm 1.18 \mathrm{Ad}$ & $34.67 \pm 2.90 \mathrm{Ac}$ \\
\hline \multirow{2}{*}{ Less Rep (mol\%) } & $0 \mathrm{mM}$ & $1.13 \pm 0.07 \mathrm{Ac}$ & $1.06 \pm 0.14 \mathrm{Ac}$ & $0.95 \pm 0.04 \mathrm{Ac}$ \\
\hline & $400 \mathrm{mM}$ & $1.13 \pm 0.18 \mathrm{Ac}$ & $1.02 \pm 0.07 \mathrm{Ac}$ & $1.01 \pm 0.14 \mathrm{Ac}$ \\
\hline \multirow{2}{*}{ DBI } & $0 \mathrm{mM}$ & $6.47 \pm 0.22 \mathrm{Ac}$ & $5.94 \pm 0.76 \mathrm{Ac}$ & $6.10 \pm 0.25 \mathrm{Ac}$ \\
\hline & $400 \mathrm{mM}$ & $5.25 \pm 0.48 \mathrm{Ac}$ & $5.67 \pm 0.31 \mathrm{Ac}$ & $3.77 \pm 0.65 \mathrm{Bd}$ \\
\hline
\end{tabular}

Salt led to a significant decrease in the TFA content, while temperature did not change this parameter. Similarly, high salt concentration $(400 \mathrm{mM} \mathrm{NaCl})$ and high temperature $\left(45^{\circ} \mathrm{C}\right)$ significantly decreased the amount of linolenic acid (C18:3), with the latter one only at $400 \mathrm{mM} \mathrm{NaCl}$. By contrast, both single stresses significantly increased linoleic acid (C18:2); however, this increase was more evident under salt conditions. Likewise, palmitic acid (C16:0) and oleic acid (C18:1) significantly increased under salt conditions (only at $45^{\circ} \mathrm{C}$ ). Additionally, increasing temperatures led to a significant increase of $\mathrm{C} 16: 0$ and C18:1; however, for C16:0, this increase was only significant at $400 \mathrm{mM} \mathrm{NaCl}$. Oppositely, both single stresses significantly decreased DBI at the harshest stress condition ( $400 \mathrm{mM}$ $\left.\mathrm{NaCl}, 45^{\circ} \mathrm{C}\right)$.

\subsection{Antioxidant Enzymes}

Both single and combined exposure to salt and heat stress significantly increased ascorbate peroxidase (APX) activity in C. glauca branchlets (Figure 5a). A similar pattern of variation was observed for catalase (CAT), in which single salt and heat conditions significantly increased CAT activity up to, and including, $35^{\circ} \mathrm{C}$. The harshest stress condition $\left(400 \mathrm{mM} \mathrm{NaCl}, 45^{\circ} \mathrm{C}\right)$ significantly decreased CAT activity with respect to the levels at $35^{\circ} \mathrm{C}$, although to levels higher than the control $\left(0 \mathrm{mM} \mathrm{NaCl}, 26^{\circ} \mathrm{C}\right)$ (Figure $5 \mathrm{~b}$ ). Glutathione reductase (GR) activity also significantly increased under single salt and heat conditions, with the most pronounced effect of salt observed at the lowest temperature $\left(26^{\circ} \mathrm{C}\right)$. The highest temperature $\left(45^{\circ} \mathrm{C}\right)$ resulted in significantly decreased GR activity at both control $(0 \mathrm{mM} \mathrm{NaCl})$ and $400 \mathrm{mM} \mathrm{NaCl}$ (Figure 5c). Similarly, superoxide dismutase 
(SOD) activity significantly increased under both salt (at 26 and $35^{\circ} \mathrm{C}$ ) and heat (only at $0 \mathrm{mM} \mathrm{NaCl}$ ) conditions. By contrast, at $45^{\circ} \mathrm{C}$, salt conditions decreased SOD activity; however, such decrease did not reduce SOD activity at the harshest stress conditions (Figure 5d).

(a)

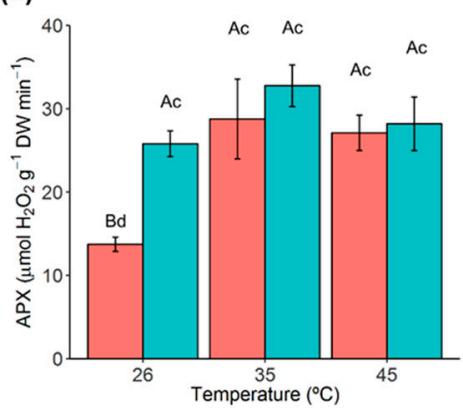

(c)

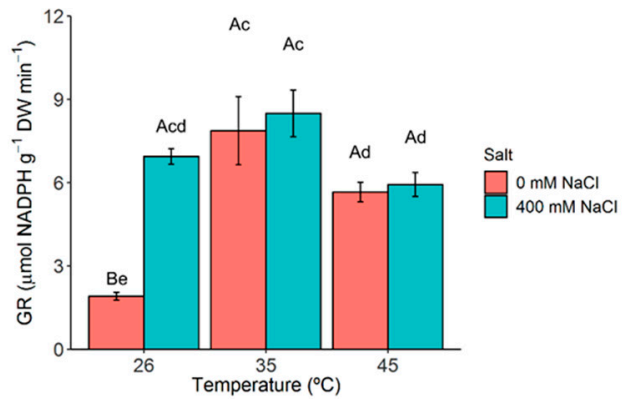

(b)

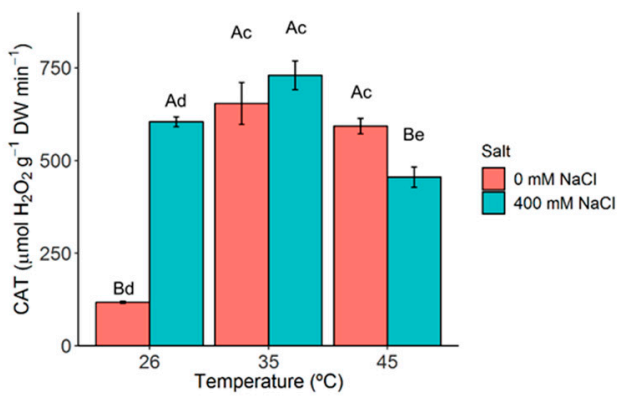

(d)

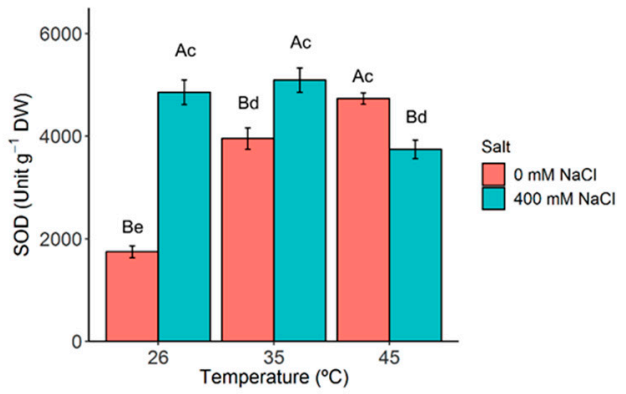

Figure 5. Evaluation of antioxidant enzyme activities in C. glauca branchlets under the single and combined exposure to salt $(0$ and $400 \mathrm{mM} \mathrm{NaCl})$ and temperature $\left(26,35\right.$ and $\left.45^{\circ} \mathrm{C}\right)$ conditions. (a) ascorbate peroxidase (APX). (b) cellular catalase (CAT). (c) glutathione reductase (GR). (d) superoxide dismutase (SOD). Bars represent the mean values \pm SE from three to five independent measurements. Two-way ANOVA $(p<0.05)$ followed by Tukey's HSD test was for performed for means comparison and different letters express significant differences between $[\mathrm{NaCl}]$ for the same temperature $(\mathrm{A}, \mathrm{B})$ or between temperature for the same $[\mathrm{NaCl}](\mathrm{c}, \mathrm{d}$, e) with $\mathrm{A}$ and $\mathrm{c}$ representing the highest values.

\subsection{GC-TOF-MS Primary Metabolite Profiling Analysis}

Primary metabolite profiling analysis allowed the detection of 36 metabolites in C. glauca branchlets (Figure 6a, Table S2). Under salt stress, two-way ANOVA analysis revealed that the relative levels of 11 primary metabolites significantly changed (fructose, glucose, rhamnose, sucrose, glutamate, proline, 4-hydroxy-proline, aspartate, malate, threonate and malonate) as shown in the Venn diagram (Figure 6b, Table S2). Of these, only proline significantly increased (2-fold), whereas fructose, glucose, rhamnose, sucrose, glutamate, 4-hydroxy-proline, aspartate, malate, threonate and malonate significantly decreased. By contrast, heat stress significantly changed the levels of the amino acids tryptophan, tyrosine, valine and glutamine (Figure 6a,b, Table S2). All these metabolites significantly increased at $35^{\circ} \mathrm{C}$ (up to 2-fold) and $45^{\circ} \mathrm{C}$ (up to 6-fold). On the other hand, galactinol, alanine, $\gamma$-aminobutyric acid (GABA) and fumarate were shown to significantly change by both single stresses, but not by combined salt-heat stress (Figure 6a,b, Table S2). These metabolites significantly decreased at $400 \mathrm{mM} \mathrm{NaCl}$, and significantly increased under increasing temperatures of 35 and $45{ }^{\circ} \mathrm{C}$ (up to 5-fold). Lastly, single heat and combined salt-heat stresses significantly changed the levels of isoleucine and leucine, which increased up to 3-fold (heat stress) and up to 7-fold (salt-heat stress) (Figure 6a,b, Table S2). 
(a)

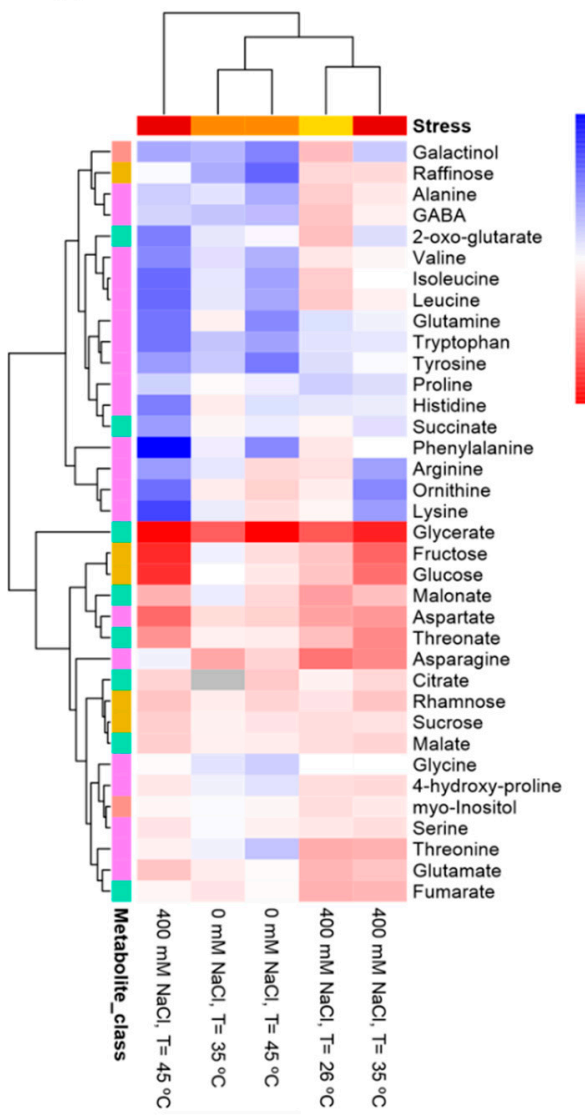

(b)

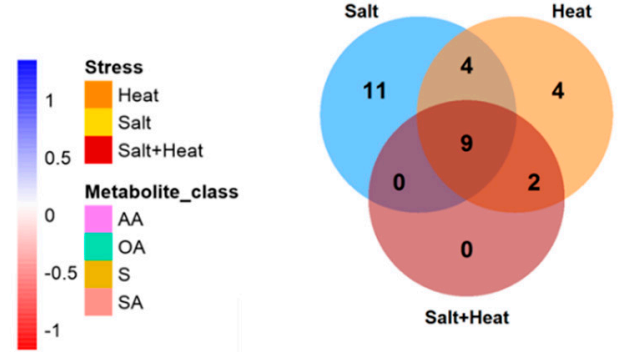

(c)

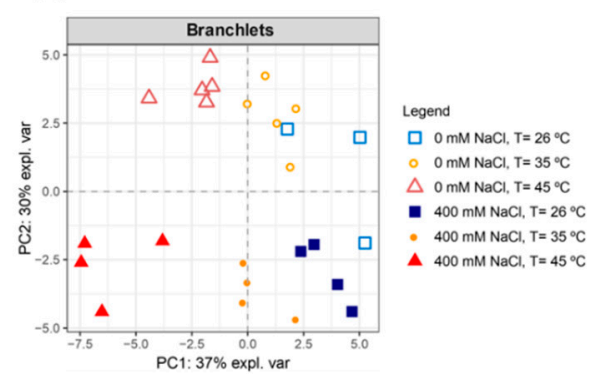

Figure 6. GC-TOF-MS primary metabolite profiling analysis. (a) Heatmap showing metabolite responses in C. glauca branchlets under the single and combined exposure to salt ( 0 and $400 \mathrm{mM} \mathrm{NaCl})$ and temperature $\left(26,35\right.$ and $45{ }^{\circ} \mathrm{C}$ ) conditions. Relative values are normalised to the internal standard (ribitol) and dry weight (DW) of the samples. False-colour imaging was performed on $\log _{10}$-transformed GC-TOF-MS data. Grey-colour squares represent not detected (n.d.) values. AA-amino acids, OA-organic acids, S-sugars, SA-sugar alcohols. (b) Venn diagram showing the number of metabolites which levels were shown to significantly change in $C$. glauca branchlets under the single and combined exposure to salt $(0$ and $400 \mathrm{mM} \mathrm{NaCl})$ and temperature $\left(26,35\right.$ and $\left.45{ }^{\circ} \mathrm{C}\right)$ conditions. Two-way ANOVA $(p<0.05)$ followed by Tukey's HSD test was performed for means comparison. (c) Principal component analysis (PCA) score plots of the primary metabolite profiles in the branchlets of $C$. glauca plants under the single and combined exposure to salt $(0$ and $400 \mathrm{mM} \mathrm{NaCl})$ and temperature $\left(26,35\right.$ and $\left.45^{\circ} \mathrm{C}\right)$ conditions.

Under both single and combined salt-heat stresses, nine primary metabolites were shown to significantly change; namely, raffinose, glycine, phenylalanine, histidine, ornithine, arginine, lysine, threonine and glycerate (Figure 6a,b, Table S2). Of these, the most representative significant increases were found for raffinose (up to 7-fold, heat stress), glycine (up to 2-fold, heat stress), phenylalanine (up to 5-fold, heat stress; up to 22-fold, salt-heat stress), histidine (up to 5-fold, salt-heat stress), ornithine (up to 6-fold, salt-heat stress), arginine (up to 4-fold, salt-heat stress), lysine (up to 10-fold, salt-heat stress) and threonine (up to 2-fold, heat stress), while significant decreases were observed for raffinose (salt stress), ornithine (heat stress), threonine (salt stress) and glycerate (for all stresses).

PCA revealed that salt treatments $(0$ and $400 \mathrm{mM} \mathrm{NaCl})$ were separated along with the principal component 2 (PC2) (Figure 6c).

Regarding temperature conditions, it was observed that samples at $45^{\circ} \mathrm{C}$ were clearly separated from control samples $\left(26^{\circ} \mathrm{C}\right)$ by the principal component 1 (PC1).

Similarly, partial least square discriminant analysis (PLS-DA) score plot revealed a clear separation of the different heat treatments, more evident for the salt-treated plants 
between samples at 26 and $45{ }^{\circ} \mathrm{C}$ (Figure 7). A different behaviour was observed between salt samples ( 0 versus $400 \mathrm{mM} \mathrm{NaCl}$ ) at $26^{\circ} \mathrm{C}$, which did not separate. By contrast, the harshest stress condition $\left(400 \mathrm{mM} \mathrm{NaCl}, 45^{\circ} \mathrm{C}\right)$ was clearly separated from all the other conditions. The PLS-DA loading plot confirmed that the metabolites that statistically increased under both single and combined salt-heat stresses were also responsible for the discrimination of the different sample groups; phenylalanine, histidine, ornithine, arginine and lysine being clearly responsible for the separation of the harshest stress condition $\left(400 \mathrm{mM} \mathrm{NaCl}, 45^{\circ} \mathrm{C}\right)$ from the control condition $\left(0 \mathrm{mM} \mathrm{NaCl}, 26^{\circ} \mathrm{C}\right)$ (Figure 7 , Table S2).
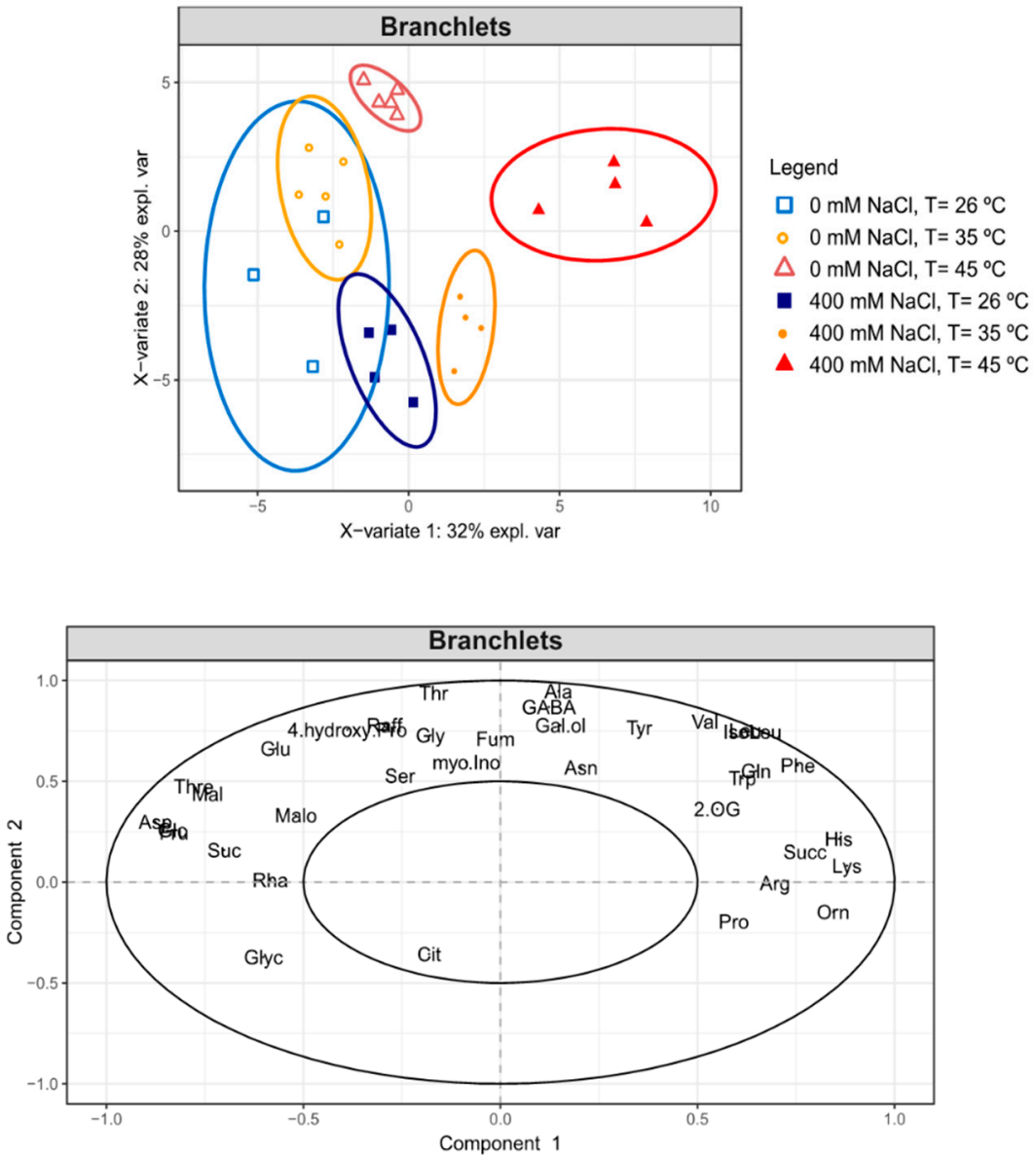

Figure 7. Partial least square discriminant analysis (PLS-DA) score and loading plot in the branchlets of C. glauca plants under the single and combined exposure to salt $(0$ and $400 \mathrm{mM} \mathrm{NaCl})$ and temperature $\left(26,35\right.$ and $\left.45^{\circ} \mathrm{C}\right)$ conditions.

\subsection{LC-HRMS/MS Target Secondary Metabolite Analysis}

Target secondary metabolite analysis allowed the detection of 23 metabolite features in C. glauca branchlets, 16 of which were identified based on their product ion spectra and mass spectral databases (Figure S2, Tables S3 and S4). In particular, flavanols, mainly kaempferol and quercetin glycosides, were the major metabolites identified. Among them, kaempferol-O-glycosides [(kaempferol 7-O-alpha-rhamnoside-D-glucoside, $\mathrm{m} / z=593$ [M$\mathrm{H}]^{-}$; kaempferol 3-O-(6"-galloyl)-beta-D-glucopyranoside, $m / z=599[\mathrm{M}-\mathrm{H}]^{-}$; kaempferol-3O-rhamnoside, $m / z=431$ [M-H $^{-}$; two kaempferol-3,7-O-bis-alpha-L-rhamnoside, $m / z=577$ $\left.\left.[\mathrm{M}-\mathrm{H}]^{-}\right)\right]$and quercetin- $O$-glycosides [(quercetin-3-O-arabinoside, $m / z=431[\mathrm{M}-\mathrm{H}]^{-}$; quercetin3-O-(6"-O-galloyl)-beta-galactoside, $m / z=615[\mathrm{M}-\mathrm{H}]^{-}$; quercetin-3-O-glucuronide, $m / z=477$ $[\mathrm{M}-\mathrm{H}]^{-}$; quercetin-7-O-rhamnoside, $m / z=447[\mathrm{M}-\mathrm{H}]^{-}$)] were identified (Figure S2, Table S3). Anthocyanins [malvidin-3-O-galactoside; cyanidin-3-O-(6-O-p-coumaryl)-pentoside], gallicacid derivatives [methyl 6-O-galloyl-beta-D-glucopyranoside $\left(\mathrm{m} / z=345[\mathrm{M}-\mathrm{H}]^{-}\right)$; methyl 4,6di-O-galloyl-beta-D-glucopyranoside $\left.\left(\mathrm{m} / \mathrm{z}=497[\mathrm{M}-\mathrm{H}]^{-}\right)\right]$and complex ellagitannin polymeric 
structures [pedunculagin and two of its isomers $\left(\mathrm{m} / \mathrm{z}=783[\mathrm{M}-\mathrm{H}]^{-}\right)$; casuarictin $(\mathrm{m} / \mathrm{z}=935$ $[\mathrm{M}-\mathrm{H}]^{-}$) and two of its isomers] were also identified (Figure S2, Table S3).

The majority of the identified secondary metabolites showed to decrease under single heat conditions while their levels were differentially changed under salt conditions (Figure S2, Table S4). The harshest stress condition $\left(400 \mathrm{mM} \mathrm{NaCl}, 45^{\circ} \mathrm{C}\right)$ increased the levels of almost all detected secondary metabolites. Subsequent two-way ANOVA analysis revealed that only kaempferol-3-O-rhamnoside, unknown_1 and kaempferol-3,7-O-bisalpha-L-rhamnoside significantly increased only by single salt stress (Table S4).

PCA did not reveal major trends among treatments (Figure S3). Subsequent PLS-DA revealed a pattern close to that of PCA (Figure S4). Indeed, the PLS-DA score plot revealed that almost all conditions clustered together. A minor discrimination between the control condition $\left(0 \mathrm{mM} \mathrm{NaCl}, 26^{\circ} \mathrm{C}\right)$ and the harshest stress condition $\left(400 \mathrm{mM} \mathrm{NaCl}, 45^{\circ} \mathrm{C}\right)$ was observed. The corresponding contribution plot revealed that most of the detected metabolites contributed to this discrimination. Indeed, the metabolites that showed to significantly change by two-way ANOVA (kaempferol-3-O-rhamnoside, unknown_1 and kaempferol-3,7-O-bis-alpha-L-rhamnoside) were the metabolites that mostly contributed to this separation.

\section{Discussion}

Single salt or heat stress promotes the development of a water deficit status within the cell $[18,37,38]$. In C. glauca branchlets, the observed significant decrease of RWC upon salt stress is consistent with previous reports in C. glauca $\mathrm{NOD}^{+}$and $\mathrm{KNO}_{3}{ }^{+}$plants submitted to salt concentrations up to $600 \mathrm{mM} \mathrm{NaCl}$ [28]. Gas exchanges $\left(\mathrm{P}_{\mathrm{n}}, \mathrm{g}_{\mathrm{s}}\right.$, Tr) were not negatively affected by heat stress in C. glauca, in line with the known environmental resilience of these plants [31]. However, these parameters were impacted under single salt stress. Interestingly, the harshest stress condition $\left(400 \mathrm{mM} \mathrm{NaCl}, 45^{\circ} \mathrm{C}\right)$ resulted in a strong impairment in $P_{n}$, which became negative. This reduction in $P_{n}$ is likely to be independent of a stomata limitation since $\mathrm{C}_{\mathrm{i}}$ did not change significantly, suggesting that a $\mathrm{CO}_{2}$ supply to the carboxylation sites was not limited [39]. With this observation being in keeping with previous results reported for C. glauca $\mathrm{KNO}_{3}{ }^{+}$plants submitted to $400 \mathrm{mM} \mathrm{NaCl}$ [28]. The significant increase of both $\mathrm{g}_{\mathrm{s}}$ and $\mathrm{Tr}$ furthermore suggests that plants neither limit stomata opening nor their rates of transpiration.

Likewise, in tomato plants, combined salt-heat stress led to a higher increase of Tr in comparison to that observed for salt stress alone [14].

Indeed, single stress alone did not affect the photosynthetic functioning in C. glauca branchlets. However, under the harshest stress condition, mesophyll limitation of photosynthesis resulted from impairments in RuBisCO and PSII, presumably promoted by the increase in temperature. At the PSII level, the harshest stress condition evoked decreases in widely used photochemical indicators of overall photosynthetic function [40]. The quantum yield of non-regulated energy dissipation of PSII $\left(\mathrm{Y}_{(\mathrm{NO})}\right)$ denoted the highest rise, in line with the higher photoinhibitory status suggested by the large increase in chronic $\left(\mathrm{PI}_{\mathrm{Chr}}\right)$ and total $\left(\mathrm{t}\right.$ Total PI) photoinhibitions. $\mathrm{Y}_{(\mathrm{NO})}$ reflects the photoinactivation and non-regulated energy dissipation in PSII (heat and fluorescence) [41-43]. $Y_{(\mathrm{NO})}$ is mostly stable, even under stressful conditions [42], with a high value pointing to constraints in radiation-energy use due to a lack of both quantum yield of non-cyclic electron transport $\left(\mathrm{Y}_{(\mathrm{II})}\right)$ and of regulated energy dissipation of PSII $\left(\mathrm{Y}_{(\mathrm{NPQ})}\right)[43,44]$.

Despite the above-mentioned negative impacts, some mechanisms of controlled energy dissipation $\left(\mathrm{q}_{\mathrm{N}}, \mathrm{Y}_{(\mathrm{NPQ})}\right.$, Zea, lutein, $\beta$-Carotene) that are well known to be crucial in the photoprotection of PSII were activated in C. glauca under stress conditions (Maxwell and Johnson, 2000 [40,45-48]. However, results show that under strict stress conditions, the triggered protective mechanisms did not prevent a significant impact at the photochemical efficiency of PSII and the biochemical (RuBisCO) performance levels.

Single salt and heat stresses are known to induce structural changes in the cellular membrane that alter its permeability, composition and fluidity [49,50]. Damages to cel- 
lular membranes are often associated with an overaccumulation of ROS that eventually induces the lipoperoxidation of membrane constituents, namely polyunsaturated fatty acids [51-53].

Single salt conditions ( $400 \mathrm{mM} \mathrm{NaCl}$ ) significantly increased electrolyte leakage in C. glauca branchlets. Indeed, it was previously demonstrated that increasing salt concentrations (400 $\mathrm{mM} \mathrm{NaCl}$ onwards) damaged membrane permeability in C. glauca $\mathrm{NOD}^{+}$and $\mathrm{KNO}_{3}{ }^{+}$plants [28]. On the other hand, any of the heat stress conditions changed membrane permeability, which indicates the ability of $C$. glauca to tolerate high temperatures. Nevertheless, at $400 \mathrm{mM} \mathrm{NaCl}, 45^{\circ} \mathrm{C}$, membrane permeability was severely impaired, whereas MDA levels remained quite stable under all stress conditions. The latter demonstrates that the oxidative degradation of membrane lipids was not triggered by any of these stress conditions. These results agree with the reported maintenance of MDA levels under increasing salt concentrations (up to $600 \mathrm{mM} \mathrm{NaCl}$ ) in C. glauca plants [32].

The impact of single salt stress on TFA and individual FA composition (with the exception of C16:1 and of less representative FAs) showed similar results to those previously reported for $C$. glauca $\mathrm{KNO}_{3}{ }^{+}$plants up to $400 \mathrm{mM} \mathrm{NaCl}$ [32]. In the case of C18:3, the most abundant FA in chloroplast membranes (ca. 70\%) [54], its levels significantly decreased under all stress conditions (more pronounced at $400 \mathrm{~m} \mathrm{M} \mathrm{NaCl}, 45^{\circ} \mathrm{C}$ ). Indeed, decreased levels of C18:3 (with simultaneous increase of C18:1 levels) were associated to high-temperature tolerance in plants, whereas the same pattern is commonly associated to impairments of cellular membranes under salt stress conditions [51,55]. By contrast, C16:0 was found to significantly increase in C. glauca branchlets at $400 \mathrm{mM} \mathrm{NaCl}, 45^{\circ} \mathrm{C}$, while DBI levels were strongly reduced. Altogether, these data indicate the ability of C. glauca to adjust FA unsaturation levels under stress conditions while maintaining constant percentages of MDA. FA modifications, together with the impairment of the membrane permeability, likely indicate damages at the membrane levels, and agrees with the impacts on the photosynthetic functioning in PSII, at the harshest stress condition.

PCA revealed that both single and combined salt-heat stresses induced differential metabolite responses. Subsequent two-way ANOVA and PLS-DA analyses allowed identifying as stress-responsive metabolites (i.e., metabolites that significantly accumulated): (i) proline (for single salt stress), (ii) raffinose, galactinol, glycine, phenylalanine, tryptophan, tyrosine, alanine, valine, GABA, glutamine, threonine, isoleucine, leucine and fumarate (for single heat stress), (iii) phenylalanine, histidine, ornithine, arginine and lysine (single salt, heat and combined salt-heat stresses). Particular attention is given below to some of these metabolites.

Single heat stress significantly increased the levels of galactinol and raffinose; galactinol being one main precursor of the raffinose family oligosaccharides (RFOs) that include raffinose. These molecules are known to accumulate in plants under stress conditions where they act as osmoprotectants [56,57].

Amino acids constituted the major metabolite class identified in C. glauca branchlets. Amongst them, glycine levels were shown to significantly increase upon both single and combined salt-heat stresses (more pronounced under heat stress). Glycine is a photorespiratory amino acid, and this result might provide further support for an increased rate of the photorespiration pathway [58-60] under both single and combined salt-heat stresses.

Amino acids derived from the shikimate pathway; namely, phenylalanine, tryptophan and tyrosine accumulated under heat stress (phenylalanine also increased under combined salt-heat stress). Overall, the accumulation of these metabolites can be a useful source of $C$ skeletons for the phenylpropanoid pathway and biosynthesis of secondary metabolites [61,62], but their accumulation is also tightly linked to the operation of the Calvin-Benson cycle, with shikimate derived amino acids being the most rapidly labelled following feeding of Arabidopsis or maize with ${ }^{13} \mathrm{CO}_{2}[63,64]$.

Branched-chain amino acids; namely, valine, isoleucine and leucine have also been reported to accumulate under abiotic stress conditions $[65,66]$. Similarly, here we reported 
increased levels of valine $\left(45^{\circ} \mathrm{C}\right)$ and higher levels of leucine and isoleucine under single heat and combined salt-heat stresses in C. glauca branchlets.

GABA, proline and ornithine are some of the amino acids derived from 2-oxo-glutarate (2-OG); an intermediate of the mitochondrial tricarboxylic acid (TCA) cycle. An increase in the levels of metabolites involved in the GABA shunt (glutamate, GABA, alanine) was suggested to act as an intermediate supplier to feed the TCA cycle during heat stress and help maintain metabolic homeostasis [67]. Indeed, the GABA shunt is known to play a role in the regulation of $C$ and $N$ metabolism $[68,69]$. Proline significantly increased under salt stress, which agrees with its well-known osmoprotectant role in plants, including salt stress [70-73]). Ornithine is one of the most abundant amino acids in Casuarina plants and has been suggested to play a role as an intermediate metabolite in $\mathrm{N}$ transport [74]. This metabolite was previously reported as a salt-stress responsive metabolite in C. glauca plants [33]. Accordingly, ornithine levels significantly increased under single salt and combined salt-heat stresses.

Threonine and lysine comprise the aspartate-family amino acids derived from the TCA-cycle intermediate oxaloacetate (OAA). Lysine significantly increased under single salt, single heat and combined salt-heat stresses; increased levels of lysine, and subsequent decrease in the levels of TCA-cycle metabolites, have been reported in plants subjected to stresses that lead to energy deprivation [75]. Indeed, fumarate significantly decreased upon single salt stress, as previously observed in C. glauca tissues [33].

Single salt and heat stresses are also known to induce oxidative stress inside plant cells $[71,76]$. An overaccumulation of ROS causes oxidative damage to cell membranes leading to lipid peroxidation, photosynthetic damages and DNA degradation [77,78]. Increased activity of enzymatic ROS scavengers; namely, APX, CAT, GR and SOD reflects an oxidative environment inside the cells [53]. In C. glauca branchlets, APX, CAT, GR and SOD significantly increased under single salt stress. The activity of these enzymes was previously demonstrated to increase in C. glauca plants upon early salt stress conditions (i.e., $200 \mathrm{mM} \mathrm{NaCl}$ [ [32]. Single heat and combined salt-heat stresses also significantly increased the activity of these enzymes; however, this increase was not so pronounced at the highest temperature $\left(45^{\circ} \mathrm{C}\right)$. These results likely contribute to the absence of lipoperoxidation under the studied stress conditions.

Important non-enzymatic ROS scavengers, including flavonoids (flavones and flavonols) have been regarded as being part of a secondary antioxidant system that complements the action of enzymatic ROS scavengers [53,79].

LC-HRMS/MS target secondary metabolite analysis in C. glauca branchlets under both single and combined salt-heat stresses allowed detecting kaempferol-O-glycosides and quercetin-O-glycosides. Two-way ANOVA analysis, together with the observed overlapping of the studied stress conditions in the PLS-DA, likely suggests that $C$. glauca branchlets did not induce the activation of a non-enzymatic ROS scavenger flavonoid-based secondary antioxidant system.

\section{Materials and Methods}

\subsection{Plant Growth Conditions and Stress Treatments}

Approximately 100 needle-like branchlets (8-10 cm long) of a 2-year old Casuarina glauca Sieb. Ex Spreng. plant was used for vegetative propagation in Broughton and Dillworth's (BD) modified medium [80] after immersion in 50 ppm of indole butyric acid (IBA) for $24 \mathrm{~h}$ [81]. 1-year old C. glauca plants were transferred into a walk-in growth chamber (10000 EHHF, ARALAB, Portugal) under environmental controlled conditions of photoperiod $(12 \mathrm{~h})$, temperature $\left(26 / 22{ }^{\circ} \mathrm{C}\right.$, day /night), relative humidity $(70 \%)$, and irradiance (ca. $500 \mu \mathrm{mol} \mathrm{m} \mathrm{m}^{-2} \mathrm{~s}^{-1}$ ). Plants were divided in 2 groups and submitted to $0 \mathrm{mM}$ (control) and $400 \mathrm{mM} \mathrm{NaCl}$ conditions. Salt enhancement in the hydroponic nutrient solution [(BD) modified medium] was gradually imposed $\left(50 \mathrm{mM} \mathrm{NaCl}_{\text {week }}^{-1}\right)$ to avoid osmotic shock and to allow the plants to express their potential for acclimation. Plants were kept for 1 more week at $400 \mathrm{mM} \mathrm{NaCl}$ before the temperature treatment began. Two 
plant groups were gradually submitted to a diurnal temperature rise $\left(1^{\circ} \mathrm{C}_{\text {day }}{ }^{-1}\right)$ to avoid heat shock, from $26^{\circ} \mathrm{C}$ (control) to $45^{\circ} \mathrm{C}$ (Figure S1). Measurements were performed at 26, 35 and $45^{\circ} \mathrm{C}$. Plants were kept for 5 days at 35 and $45^{\circ} \mathrm{C}$.

\subsection{Harvest and Storage of Casuarina Glauca Branchlets}

C. glauca branchlets were harvested at each temperature during the same daylight period after ca. $2 \mathrm{~h}\left(10-12 \mathrm{~h}\right.$ ) of irradiance ( $\left.c a .500 \mu \mathrm{mol} \mathrm{m}^{-2} \mathrm{~s}^{-1}\right)$, immediately frozen in liquid nitrogen, and stored at $-80^{\circ} \mathrm{C}$ until further analyses. Three to five independent plants in the vegetative developmental stage were used per independent treatment.

\subsection{Plant Water Relations}

Relative water content (RWC) measurements were performed as previously described in [28]. RWC was determined at midday using 9 C. glauca branchlet pieces $(1.5-2.0 \mathrm{~cm}$ long) per biological replicate.

\subsection{Gas Exchange Measurements and Chlorophyll a Fluorescence}

Gas exchanges were determined following [82]. The rates of branchlet net photosynthesis $\left(\mathrm{P}_{\mathrm{n}}\right)$, stomatal conductance to water vapour rate $\left(\mathrm{g}_{\mathrm{s}}\right)$, transpiration rate $(\mathrm{Tr})$, internal $\mathrm{CO}_{2}$ concentration $\left(\mathrm{C}_{\mathrm{i}}\right)$ and leaf temperature were assessed at each temperature condition under photosynthetic steady-state conditions after ca. $2 \mathrm{~h} \mathrm{(10-12} \mathrm{h)} \mathrm{of} \mathrm{irradi-}$ ance (ca. $500 \mu \mathrm{mol} \mathrm{m}^{-2} \mathrm{~s}^{-1}$ ) using a $\mathrm{CO}_{2} / \mathrm{H}_{2} \mathrm{O}$ portable open-system infrared gas analyser (CIRAS 1, PP Systems, Amesbury, MA, USA).

Chlorophyll (Chl) $a$ fluorescence parameters were determined on the same $C$. glauca branchlets used for the gas exchange measurements using a PAM-2000 system (H. Walz, Effeltrich, Germany) as previously described [28,44], and applying the formulae discussed elsewhere $[41,83,84]$. Measurements of the minimal fluorescence from antennae $\left(F_{0}\right)$, maximal fluorescence of the primary PSII $\left(\mathrm{F}_{\mathrm{m}}\right)$, and maximal photochemical efficiency of PSII $\left(\mathrm{F}_{\mathrm{v}} / \mathrm{F}_{\mathrm{m}}\right)$ were performed overnight dark-adapted C. glauca branchlets.

Another set of parameters was evaluated under photosynthetic steady-state conditions, using ca. $510 \mu \mathrm{mol} \mathrm{m}{ }^{-2} \mathrm{~s}^{-1}$ of actinic light and superimposed saturating flashes: $\mathrm{q}_{\mathrm{P}}, \mathrm{q}_{\mathrm{L}}$, NPQ, $Y_{(I I)}, Y_{(N P Q)}, Y_{(N O)}, F_{v}{ }^{\prime} / F_{m}{ }^{\prime}$ and PSII photoinhibition indexes (For more details, see Methods S1).

\subsection{Photosynthetic Pigment Measurements}

Carotenoids were assessed from 2-3 C. glauca branchlet pieces FW (ca. $50 \mathrm{mg}$ ). Sample processing and subsequent reverse-phase HPLC analysis were carried out as described in [85] using an end-capped $\left(\mathrm{C}_{18}\right) 5 \mu \mathrm{m}$ Spherisorb ODS-2 column $(250 \times 4.6 \mathrm{~mm})$. Detection was performed at $440 \mathrm{~nm}$ in an HPLC system (Beckman, System Gold, Tulsa, OK, USA) coupled to a diode-array detector (Model 168; Beckman, Tulsa, OK, USA). Identification and quantification were performed using individual authentic standards (Merck Life Science S.L., PT).

\subsection{Ribulose-1,5-Bisphosphate Carboxylase/Oxygenase Activity}

Ribulose-1,5-bisphosphate carboxylase/oxygenase (RuBisCO: EC 4.1.1.39) enzymatic activities were determined in ca. $200 \mathrm{mg}$ FW of frozen C. glauca branchlet tissues. Each sample was homogenised in a pre-cooled pestle and mortar using $100 \mathrm{mg}$ of insoluble polyvinylpyrrolidone (PVPP) and $1 \mathrm{~mL}$ of extraction buffer $100 \mathrm{mM}$ Tris- $\mathrm{HCl}(\mathrm{pH}$ 8) containing $10 \mathrm{mM} \mathrm{MgCl}_{2}, 15 \mathrm{mM} \mathrm{NaHCO}_{3}, 10 \mathrm{mM} \beta$-mercaptoethanol, $2 \mathrm{mM}$ ditiotreitol (DTT), $1 \%(v / v)$ Triton X-100, 10\% (v/v) glycerol and $2 \%(v / v)$ of a cOmplete ${ }^{\mathrm{TM}}$ EDTA-free Protease Inhibitor. Extracts were centrifuged $\left(16,000 \times g, 20 \mathrm{~min}, 4^{\circ} \mathrm{C}\right)$ and the supernatant was used for enzyme assays. The initial and total activities of RuBisCO were determined following the 3-PGA-dependent NADH oxidation at $340 \mathrm{~nm}$ and $25^{\circ} \mathrm{C}$, in a final volume of $1 \mathrm{~mL}$ [86]. 


\subsection{Electrolyte Leakage}

Membrane permeability was determined using 9 branchlet pieces $(c a .1 .5 \mathrm{~cm})$, rinsed 3 times, and subsequently floated in flasks containing $15 \mathrm{~mL}$ of demineralized water. Water conductivity was measured using a conductimeter (Crison GLP31, Crison Instruments, S.A., Spain) following a $24 \mathrm{~h}$ period of floating at ca. $20^{\circ} \mathrm{C}$ as described previously [87]. Total conductivity was obtained after keeping the flasks in an oven at $90{ }^{\circ} \mathrm{C}$ for $2 \mathrm{~h}$, followed by cooling down to $20^{\circ} \mathrm{C}$. Electrolyte leakage was expressed as the percentage of total conductivity.

\subsection{Lipid Analyses}

Lipid components of cellular membranes were determined as previously described [88]. Briefly, ca. $1 \mathrm{~g}$ FW frozen C. glauca branchlet tissues were boiled for $2 \mathrm{~min}$ in distilled water to stop lipolytic activities. Total lipids were extracted in a mixture of chloroform / methanol/water $(1 / 1 / 1 ; v / v / v)$. For fatty acid (FA) analysis, aliquots of total lipid extracts were saponified. Heptadecanoic acid (C17:0) was added as internal standard, followed by methyl esterification with trifluoroborane (BF3)-methanol. Two methylation replicates per sample were performed for each extract. Fatty acid methyl esters were analysed with GC-FID (CP-3380, Varian, CA, USA). For more details, see Methods S2.

\subsection{Antioxidant Enzyme Activities}

Antioxidant enzyme activities were determined from $1 \mathrm{~g} F W$ frozen $C$. glauca branchlet tissues. For superoxide dismutase (SOD; EC 1.15.1.1) and glutathione reductase (GR; EC1.6.4.2) activities, branchlet tissue was homogenised in $1.0 \mathrm{~mL}$ of $100 \mathrm{mM}$ sodium phosphate buffer ( $\mathrm{pH} 7.8$ ) containing $1 \%$ of polyvinylpyrrolidone (PVPP) and centrifuged $\left(10,000 \times g, 15 \mathrm{~min}, 4^{\circ} \mathrm{C}\right)$. The supernatant was used for the estimation of SOD and GR. SOD activity was estimated following the enzyme activity that inhibited the photoreduction of NBT to blue formazan by 50\% [89]. GR activity was measured following the absorbance decrease at $340 \mathrm{~nm}$ corresponding to the NADPH oxidation rate [90].

For catalase (CAT; EC 1.11.1.6), branchlet tissue was homogenised in $1.0 \mathrm{~mL}$ of $100 \mathrm{mM}$ sodium phosphate buffer ( $\mathrm{pH}$ 7.0) containing 1\% PVPP followed by centrifugation $\left(10,000 \times g, 20 \mathrm{~min}, 4^{\circ} \mathrm{C}\right)$. The supernatant was used for the estimation of CAT. CAT activity was estimated based on the decrease in absorbance of $\mathrm{H}_{2} \mathrm{O}_{2}$ at $240 \mathrm{~nm}$ [91].

For ascorbate peroxidase (APX; EC 1.11.1.11), the homogenisation step also included $2.0 \mathrm{mM}$ ascorbic acid followed by centrifugation $\left(10,000 \times g, 20 \mathrm{~min}, 4^{\circ} \mathrm{C}\right)$. APX activity was estimated through ascorbate consumption monitored at $290 \mathrm{~nm}$, using an extinction coefficient of $2.8 \mathrm{mM}^{-1} \mathrm{~cm}^{-1}$ [92]. All activity assays were performed at $25^{\circ} \mathrm{C}$.

\subsection{GC-TOF-MS Primary Metabolite Profiling Analysis}

Primary metabolites were extracted from $100 \mathrm{mg}$ FW fine powder of $C$. glauca branchlet tissue in $1400 \mu \mathrm{L}$ methanol containing $60 \mu \mathrm{L}$ of ribitol $\left(0.2 \mathrm{mg} \mathrm{mL}^{-1}\right.$ in water) as internal standard [93]. For more details, see Methods S3. Biological variations were controlled by analysing fatty acid methyl esters (FAMEs) internal standard markers and a quality control (QC) standard solution of 41 pure reference compounds (i.e., the most detected and abundant metabolites) throughout the analysis. Primary metabolite profiling analysis of the derivatised samples ( $1 \mu \mathrm{L}$ aliquots) was performed on an Agilent $6890 \mathrm{~N}$ gas chromatograph (Agilent Technologies, Böblingen, Germany) and a LECO Pegasus III TOF-MS running in electron ionisation (EI) mode (LECO Instrumente, Mönchengladbach, Germany) [93]. For more details, see Methods S3. GC-TOF-MS data were evaluated using the automated mass spectral deconvolution and identification system (AMDIS) software. Primary metabolites were annotated using the TagFinder software [94], matching mass spectral and retention time index to the reference collection of authenticated standard substances from the Golm Metabolome Database (GMD, http:/ /gmd.mpimpgolm.mpg.de, last accessed on 12 December 2019) [95]. The relative abundance of primary metabolites was normalised considering the FW/dry weight (DW) ratio and the signal intensity of 
the internal standard (ribitol). Metadata information following the minimum reporting standard guidelines of the Metabolomics Standard Initiative (MSI) [96] can be found in Table S5.

\subsection{LC-HRMS/MS Target Secondary Metabolite Analysis}

Secondary metabolites were extracted from $100 \mathrm{mg}$ FW fine powder of C. glauca branchlet tissue in $500 \mu \mathrm{L}$ methanol $80 \%(v / v)$ containing isovitexin $\left(4 \mu \mathrm{g} \mathrm{mL}^{-1}\right)$ as internal standard. LC-HRMS/MS was performed as previously described [97]. For more details, see Methods S4. Metabolite annotation was performed following the approach described in [35]. MS/MS data interpretation was performed by matching the spectra against the METLIN MS/MS (https:/ / metlin.scripps.edu/, last accessed on 12 December 2019) [98], NORMAN MassBank (http:/ / massbank.eu/MassBank/, last accessed on 12 December 2019) and the MoNA (MassBank of North America) (http:/ / mona.fiehnlab.ucdavis.edu/, last accessed on 12 December 2019) high-resolution mass spectral databases. Metadata information following the minimum reporting standard guidelines of the MSI [96] can be found in Table S5.

\subsection{Statistical Data Analyses}

Statistically significant differences between single and combined salt-heat stress treatments were determined with a two-way ANOVA, using the $\mathrm{R}$ software environment 3.4.3 [99]. The Benjamini-Hochberg false discovery rate (FDR) correction was used to adjust $p$-values (only for the metabolomics dataset) prior to the Tukey's honestly significant difference (HSD) test. Fold-changes between conditions and the control for each metabolite were determined and $\log _{10}$ transformed for heatmap plotting (R package pheatmap) [100]. Principle component analysis (PCA) and partial least squares discriminant analysis (PLSDA) were performed on $\log _{10}$ transformed primary metabolite relative response values using the R package "mixOmics" [101]. PCA was applied using unit variance scaling, and PLS-DA model reliability was assessed using the leave-one-out cross-validation embedded in the R package "mixOmics" [101]. Venn diagrams were obtained using the R package VennDiagram [102].

\section{Conclusions}

The present study represents a considerable advance in the field of actinorhizal plants, which was to date supported by few integrative physiological and metabolomics studies performed thus far in the model actinorhizal plant, C. glauca. We found that C. glauca could withstand naturally occurring high salt and heat stress conditions, but the harshest stress condition was demonstrated to severely compromise C. glauca survival. Indeed, the observed (i) stress-induced activation of plant photoprotection mechanisms ( $\mathrm{q}_{\mathrm{N}}$, $\mathrm{Y}_{(\mathrm{NPQ})}$, Zea, lutein, $\beta$-Carotene), (ii) increased activity of enzymatic ROS scavengers, and (iii) stress-induced activation of $\mathrm{C}$ and $\mathrm{N}$ metabolic pathways did not prevent a mesophyll limitation of photosynthesis. Faced with this situation, C. glauca stress resilience could not be maintained, and thus, climate change is a most urgent threat not only to stress intolerant plants but also to highly resilient plants and, as such, may ultimately represent existential stress to life on earth.

Supplementary Materials: The following are available online at https:/ / www.mdpi.com/article/10 .3390/metabo11090593/s1, Figure S1 Diagram of the experi-mental design, Figure S2 LC-HRMS/MS secondary metabolite analysis, Figure S3 principal component analysis (PCA) score plot of the secondary metabolite profiles, Figure S4 partial least square discriminant analysis (PLS-DA) of the secondary metabolite profiles, Table S1 photosyn-thetic pigments-HPLC chromatograms, Table S2 GC-TOF-MS primary metabolite profiling of C. glauca branchlets under the single and combined exposure to salt $(0$ and $400 \mathrm{mM} \mathrm{NaCl})$ and temperature $\left(26,35\right.$ and $\left.45^{\circ} \mathrm{C}\right)$ conditions, Table S3 annotation of the secondary metabolites de-tected by LC-HRMS/MS in C. glauca branchlets, Table S4 LC-HRMS/MS secondary metabolite analysis of C. glauca branchlets under the single and combined exposure to salt $(0$ and $400 \mathrm{mM} \mathrm{NaCl})$ and temperature $\left(26,35\right.$ and $\left.45^{\circ} \mathrm{C}\right)$ conditions, 
Table S5 metabolomics metadata infor-mation, Methods S1 detailed description of the chlorophyll a parameters evaluated under pho-tosynthetic steady-state conditions, Methods S2 lipid analyses, Methods S3 primary metabolite extraction, derivatisation and GC-TOF-MS analysis, Methods S4 secondary metabolite extraction and LC-HRMS analysis [103-106].

Author Contributions: Conceptualization, C.A., J.C.R. and A.I.R.-B.; methodology, C.A., A.R.F., J.C.R. and A.I.R.-B.; software, T.F.J.; validation, C.A.; formal analysis, T.F.J.; investigation, T.F.J., J.C.R., I.P.P., P.S.-C., A.E.L., A.P.R. and S.A.; resources, C.A., J.C.R., P.S.-C. and A.R.F.; data curation, T.F.J.; writing—original draft preparation, T.F.J.; writing—review and editing, C.A., A.R.F., J.C.R., A.I.R.-B., P.S.-C., I.P.P., A.E.L., A.P.R. and S.A.; visualization, T.F.J.; supervision, C.A.; project administration, C.A. and A.I.R.-B.; funding acquisition, C.A., A.R.F., J.C.R. and A.I.R.-B. All authors have read and agreed to the published version of the manuscript.

Funding: This work received funding support from Fundação para a Ciência e a Tecnologia (FCT), Portugal through the project PTDC/AGR-FOR/4218/2012, and the research units UID/Multi/04551/ 2013 (GREEN-IT), UIDB/00239/2020 (CEF) and UIDP/04035/2020 (GeoBioTec). C.A. acknowledges the FCT Investigator Program (IF/00376/2012/CP0165/CT0003). T.F.J. acknowledges FCT (PD/BD/113475/2015) and ITQB NOVA International PhD Program Plants for Life (PD/00035/2013). A.R.F. and S.A. are supported by the European Union's Horizon 2020 research and innovation programme, project PlantaSYST (SGA-CSA No. 739582 under FPA No. 664620).

Institutional Review Board Statement: Not applicable.

Informed Consent Statement: Not applicable.

Data Availability Statement: The data presented in this study are available in article and Supplementary Materials.

Acknowledgments: The authors also thank Pedro Gomes (ITQB NOVA, currently at Faculty of Pharmacy, ULisboa) and Paula Alves (ISA/UL) for their valuable support with the C. glauca biological experiment. Thiago Alexandre Moraes (MPI-MP, currently at Crop Science Centre, UK) is acknowledged for the fruitful discussions about ANOVA statistics and valuable help with R software.

Conflicts of Interest: The authors declare no conflict of interest. The funders had no role in the design of the study; in the collection, analyses, or interpretation of data; in the writing of the manuscript, or in the decision to publish the results.

\section{References}

1. IPCC Core Writing Team. Climate Change 2014: Synthesis Report. Contribution of Working Groups I, II and III to the Fifth Assessment Report of the Intergovernmental Panel on Climate Change; Intergovernmental Panel on Climate Change: Geneva, Switzerland, 2014.

2. Hirayama, T.; Shinozaki, K. Research on plant abiotic stress responses in the post-genome era: Past, present and future. Plant J. 2010, 61, 1041-1052. [CrossRef]

3. Pereira, A. Plant abiotic stress challenges from the changing environment. Front. Plant Sci. 2011, 7, 1123. [CrossRef]

4. Mittler, R. Abiotic stress, the field environment and stress combination. Trends Plant Sci. 2006, 11, 15-19. [CrossRef]

5. Prasch, C.M.; Sonnewald, U. Simultaneous application of heat, drought, and virus to Arabidopsis plants reveals significant shifts in signalling networks. Plant Physiol. 2013, 162, 1849-1866. [CrossRef]

6. Rasmussen, S.; Barah, P.; Suarez-Rodriguez, M.C.; Bressendorff, S.; Friis, P.; Costantino, P.; Bones, A.M.; Nielsen, H.B.; Mundy, J. Transcriptome responses to combinations of stresses in Arabidopsis. Plant Physiol. 2013, 161, 1783-1794. [CrossRef]

7. Obata, T.; Witt, S.; Lisec, J.; Palacios-Rojas, N.; Florez-Sarasa, I.; Yousfi, S.; Araus, J.L.; Cairns, J.E.; Fernie, A.R. Metabolite profiles of maize leaves in drought, heat and combined stress field trials reveal the relationship between metabolism and grain yield. Plant Physiol. 2015, 69, 2665-2683. [CrossRef]

8. Pandey, P.; Ramegowda, V.; Senthil-Kumar, M. Shared and unique responses of plants to multiple individual stresses and stress combinations: Physiological and molecular mechanisms. Front. Plant Sci. 2015, 6, 723. [CrossRef]

9. Shaar-Moshe, L.; Blumwald, E.; Peleg, Z. Unique physiological and transcriptional shifts under combinations of salinity, drought, and heat. Plant Physiol. 2017, 174, 421-434. [CrossRef]

10. Suzuki, N.; Rivero, R.M.; Shulaev, V.; Blumwald, E.; Mittler, R. Abiotic and biotic stress combinations. New Phytol. 2014, 203, 32-43. [CrossRef]

11. Jorge, T.F.; António, C. Plant metabolomics in a changing world: Metabolite responses to abiotic stress combinations, plant, abiotic stress and responses to climate change. In Plant, Abiotic Stress and Responses to Climate Change; Andjelkovic, V., Ed.; InTechOpen Publishing: London, UK, 2017; pp. 111-132. [CrossRef]

12. Zandalinas, S.I.; Mittler, R.; Balfagón, D.; Arbona, V.; Gómez-Cadenas, A. Plant adaptations to the combination of drought and high temperatures. Physiol. Plant 2018, 162, 2-12. [CrossRef] 
13. Keles, Y.; Oncel, I. Response of antioxidative defence system to temperature and water stress combinations in wheat seedlings. Plant Sci. 2002, 163, 783-790. [CrossRef]

14. Rivero, R.M.; Mestre, T.C.; Mittler, R.; Rubio, F.; Garcia-Sanchez, F.; Martinez, V. The combined effect of salinity and heat reveals a specific physiological, biochemical and molecular responses in tomato plants. Plant Cell Environ. 2014, 37, 10591073. [CrossRef] [PubMed]

15. Zhang, H.; Sonnewald, U. Differences and commonalities of plant responses to single and combined stresses. Plant J. 2017, 90, 839-855. [CrossRef] [PubMed]

16. Munns, R.; Tester, M. Mechanisms of salinity tolerance. Annu. Rev. Plant Biol. 2008, 59, 651-681. [CrossRef] [PubMed]

17. Yang, Y.; Guo, Y. Elucidating the molecular mechanisms mediating plant salt-stress responses. New Phytol. 2018, 217, 523-539. [CrossRef]

18. Wahid, A.; Gelani, S.; Ashraf, M.; Foolad, M.R. Heat tolerance in plants: An overview. Environ. Exp. Bot. 2007, 61, 199-223. [CrossRef]

19. Mittler, R.; Finka, A.; Goloubinoff, P. How do plants feel the heat? Trends Biochem. Sci. 2012, 37, 118-125. [CrossRef]

20. Slama, I.; Abdelly, C.; Bouchereau, A.; Flowers, T.; Savouré, A. Diversity, distribution and roles of osmoprotective compounds accumulated in halophytes under abiotic stress. Ann. Bot. 2015, 115, 433-447. [CrossRef]

21. Potgieter, L.J.; Richardson, D.M.; Wilson, J.R.U. Casuarina: Biogeography and ecology of an important tree genus in a changing world. Biol. Invasions 2014, 16, 609-633. [CrossRef]

22. Li, H.L.; Wang, W.; Mortimer, P.E.; Li, R.Q.; Li, D.Z.; Hyde, K.D.; Xu, J.C.; Soltis, D.E.; Chen, Z.D. Large-scale phylogenetic analyses reveal multiple gains of actinorhizal nitrogen-fixing symbioses in angiosperms associated with climate change. Sci. Rep. 2015, 5, 14023. [CrossRef] [PubMed]

23. Diagne, N.; Arumugam, K.; Ngom, M.; Nambiar-Veetil, M.; Franche, C.; Narayanan, K.K.; Laplaze, L. Use of Frankia and actinorhizal plants for degraded lands reclamation. Biomed. Res. Int. 2013, 2013, 948258. [CrossRef]

24. Zhong, C.; Mansour, S.; Nambiar-Veetil, M.; Bogusz, D.; Franche, C. Casuarina glauca: A model tree for basic research in actinorhizal symbiosis. J. Biosci. 2013, 38, 815-823. [CrossRef] [PubMed]

25. Sayed, W.F. Improving Casuarina growth and symbiosis with Frankia under different soil and environmental conditions-Review. Folia Microbiol. 2011, 56, 1-9. [CrossRef]

26. Huang, J.; Ji, M.; Xie, Y.; Wang, S.; He, Y.; Ran, J. Global semi-arid climate change over last 60 years. Clim. Dyn. 2016, 46, 1131-1150. [CrossRef]

27. Lionello, P.; Scarascia, L. The relation between climate change in the Mediterranean region and global warming. Reg. Environ. Chang. 2018, 18, 1481-1493. [CrossRef]

28. Batista-Santos, P.; Duro, N.; Rodrigues, A.P.; Semedo, J.N.; Alves, P.; da Costa, M.; Graça, I.; Pais, I.P.; Scotti-Campos, P.; Lidon, F.C.; et al. Is salt stress tolerance in Casuarina glauca Sieb. ex Spreng. associated with its nitrogen-fixing root-nodule symbiosis? An analysis at the photosynthetic level. Plant Physiol. Biochem. 2015, 96, 97-109. [CrossRef] [PubMed]

29. Da Costa, M.; Duro, N.; Batista-Santos, P.; Ramalho, J.C.; Ribeiro-Barros, A.I. Validation of candidate reference genes for qRTCR studies in symbiotic and non-symbiotic Casuarina glauca Sieb. ex Spreng. under salinity conditions. Symbiosis 2015, 66, 21-35. [CrossRef]

30. Duro, N.; Batista-Santos, P.; da Costa, M.; Maia, R.; Castro, I.V.; Ramos, M.; Ramalho, J.C.; Pawlowski, K.; Máguas, C.; RibeiroBarros, A. The impact of salinity on the symbiosis between Casuarina glauca Sieb. ex Spreng. and $\mathrm{N}_{2}$-fixing Frankia bacteria based on the analysis of Nitrogen and Carbon metabolism. Plant Soil 2016, 398, 327-337. [CrossRef]

31. Ribeiro-Barros, A.I.; da Costa, M.; Duro, N.; Graça, I.; Batista-Santos, P.; Jorge, T.F.; Lidon, F.J.C.; Pawlowski, K.; António, C.; Ramalho, J.C. An integrated approach to understand the mechanisms underlying salt stress tolerance in Casuarina glauca and its relation with nitrogen-fixing Frankia Thr. Symbiosis 2016, 70, 111-116. [CrossRef]

32. Scotti-Campos, P.; Duro, N.; da Costa, M.; Pais, I.P.; Rodrigues, A.P.; Batista-Santos, P.; Semedo, J.N.; Leitão, A.E.; Lidon, F.C.; Pawlowski, K.; et al. Antioxidative ability 9 integrity in salt-induced responses of Casuarina glauca Sieber ex Spreng. in symbiosis with $\mathrm{N}_{2}$-fixing Frankia Thr or supplemented with mineral nitrogen. J. Plant Physiol. 2016, 196, 60-69. [CrossRef]

33. Jorge, T.F.; Duro, N.; da Costa, M.; Florian, A.; Ramalho, J.C.; Ribeiro-Barros, A.I.; Fernie, A.R.; António, C. GC-TOF-MS analysis reveals salt stress-responsive primary metabolites in Casuarina glauca tissues. Metabolomics 2017, 13, 95. [CrossRef]

34. Jorge, T.F.; Florêncio, M.H.; Ribeiro-Barros, A.I.; António, C. Quantification and structural characterization of raffinose family oligosaccharides in Casuarina glauca plant tissues by porous graphitic carbon electrospray quadrupole ion trap mass spectrometry. Int. J. Mass Spectrom. 2017, 413, 127-134. [CrossRef]

35. Jorge, T.F.; Tohge, T.; Wendenburg, R.; Ramalho, J.C.; Lidon, F.C.; Ribeiro-Barros, A.I.; Fernie, A.R.; António, C. Salt-stress secondary metabolite signatures involved in the ability of Casuarina glauca to mitigate oxidative stress. Environ. Exp. Bot. 2019, 166, 103808. [CrossRef]

36. Graça, I.; Mendes, V.M.; Marques, I.; Duro, N.; da Costa, M.; Ramalho, J.C.; Pawlowski, K.; Manadas, B.; Ricardo, C.P.P.; Ribeiro-Barros, A.I. Comparative proteomic analysis of nodulated and non-nodulated Casuarina glauca Sieb. ex Spreng. Grown under salinity conditions using sequential window acquisition of all theoretical mass spectra (SWATH-MS). Int. J. Mol. Sci. 2020, 21, 78. [CrossRef]

37. Chaves, M.M.; Flexas, J.; Pinheiro, C. Photosynthesis under drought and salt stress: Regulation mechanisms from whole plant to cell. Ann. Bot. 2009, 103, 551-560. [CrossRef] [PubMed] 
38. Negrão, S.; Schmöckel, S.M.; Tester, M. Evaluating physiological responses of plants to salinity stress. Ann. Bot. 2017, 119, 13-26. [CrossRef]

39. Medeira, C.; Quartin, V.; Maia, I.; Diniz, I.; Matos, M.C.; Semedo, J.N.; Scotti-Campos, P.; Ramalho, J.C.; Pais, I.P.; Ramos, P.; et al. Cryptogein and capsicein promote defence responses in Quercus suber against Phytophthora cinnamomi Infection. Eur. J. Plant Pathol. 2012, 134, 145-159. [CrossRef]

40. Baker, N.R. Chlorophyll fluorescence: A probe of photosynthesis in vivo. Annu. Rev. Plant Biol. 2008, 59, 89-113. [CrossRef]

41. Kramer, D.M.; Johnson, G.; Kiirats, O.; Edwards, G.E. New fluorescence parameters for the determination of QA redox state and excitation energy fluxes. Photosynth. Res. 2004, 79, 209-218. [CrossRef]

42. Busch, F.; Hunter, N.P.A.; Ensminger, I. Biochemical constrains limit the potential of the photochemical reflectance index as a predictor of effective quantum efficiency of photosynthesis during the winter spring transition in Jack pine seedlings. Funct. Plant Biol. 2009, 36, 1016-1026. [CrossRef]

43. Huang, W.; Zhang, S.B.; Cao, K.F. Cyclic electron flow plays an important role in photoprotection of tropical trees illuminated at temporal chilling temperature. Plant Cell Physiol. 2011, 52, 297-305. [CrossRef]

44. Rodrigues, W.P.; Martins, M.Q.; Fortunato, A.S.; Rodrigues, A.P.; Semedo, J.N.; Simões-Costa, M.C.; Pais, I.P.; Leitão, A.E.; Colwell, F.; Goulao, L.; et al. Long-term elevated air $\left[\mathrm{CO}_{2}\right]$ strengthens photosynthetic functioning and mitigates the impact of supra-optimal temperatures in tropical Coffea arabica and Coffea canephora species. Glob. Chang. Biol. 2016, 22, 415-431. [CrossRef]

45. Maxwell, K.; Johnson, G.N. Chlorophyll fluorescence-A practical guide. J. Exp. Bot. 2000, 345, 659-668. [CrossRef]

46. Fortunato, A.; Lidon, F.C.; Batista-Santos, P.; Leitão, A.E.; Pais, I.P.; Ribeiro, A.I.; Ramalho, J.C. Biochemical and molecular characterization of the antioxidative system of Coffea sp. under cold conditions in genotypes with contrasting tolerance. J. Plant Physiol. 2010, 167, 333-342. [CrossRef] [PubMed]

47. Ashraf, M.; Harris, P.J.C. Photosynthesis under stressful environments: An overview. Photosynthetica 2013, 51, 163-190. [CrossRef]

48. Martins, M.Q.; Rodrigues, W.P.; Fortunato, A.S.; Leitão, A.E.; Rodrigues, A.P.; Pais, I.P.; Martins, L.D.; Silva, M.J.; Reboredo, F.H.; Partelli, F.L.; et al. Protective response mechanisms to heat stress in interaction with high $\left[\mathrm{CO}_{2}\right]$ conditions in Coffea spp. Front. Plant Sci. 2016, 7, 947. [CrossRef]

49. Mansour, M.M.F. Plasma membrane permeability as an indicator of salt tolerance in plants. Biol. Plant 2013, 57, 1-10. [CrossRef]

50. Hasanuzzaman, M.; Nahar, K.; Alam, M.M.; Roychowdhury, R.; Fujita, M. Physiological, biochemical, and molecular mechanisms of heat stress tolerance in plants. Int. J. Mol. Sci. 2013, 14, 9643-9684. [CrossRef]

51. Murakami, Y.; Tsuyama, M.; Kobayashi, Y.; Kodama, H.; Iba, K. Trienoic fatty acids and plant tolerance of high temperature. Science 2000, 287, 476-479. [CrossRef]

52. Sakamoto, T.; Murata, N. Regulation of the desaturation of fatty acids and its role in tolerance to cold and salt stress. Curr. Opin. Microbiol. 2002, 5, 206-210. [CrossRef]

53. Das, K.; Roychoudhury, A. Reactive oxygen species (ROS) and response of antioxidants as ROS-scavengers during environmental stress in plants. Front. Environ. Sci. 2014, 2, 53. [CrossRef]

54. Yaeno, T.; Matsuda, O.; Iba, K. Role of chloroplast trienoic fatty acids in plant disease defense responses. Plant J. 2004, 40, 931-941. [CrossRef] [PubMed]

55. Upchurch, R.G. Fatty acid unsaturation, mobilization, and regulation in the response of plants to stress. Biotechnol. Lett. 2008, 30, 967-977. [CrossRef]

56. ElSayed, A.I.; Rafudeen, M.S.; Golldack, D. Physiological aspects of raffinose family oligosaccharides in plants: Protection against abiotic stress. Plant Biol. 2014, 6, 1-8. [CrossRef]

57. Sengupta, S.; Mukherjee, S.; Basak, P.; Majumder, A.L. Significance of galactinol and raffinose family oligosaccharide synthesis in plants. Front. Plant Sci. 2015, 6, 656. [CrossRef]

58. Bauwe, H.; Hagemann, M.; Fernie, A.R. Photorespiration: Players, partners and origin. Trends Plant Sci. 2010, 15, 330-336. [CrossRef]

59. Timm, S.; Florian, A.; Wittmiß, M.; Jahnke, K.; Hagemann, M.; Fernie, A.R.; Bauwe, H. Serine acts as a metabolic signal for the transcriptional control of photorespiration-related genes in Arabidopsis. Plant Physiol. 2013, 162, 379-389. [CrossRef]

60. Eisenhut, M.; Bräutigam, A.; Timm, S.; Florian, A.; Tohge, T.; Fernie, A.R.; Bauwe, H.; Weber, A.P.M. Photorespiration is crucial for dynamic response of photosynthetic metabolism and stomatal movement to altered $\mathrm{CO}_{2}$ availability. Mol. Plant 2017, 10, 47-61. [CrossRef]

61. Tohge, T.; Watanabe, M.; Hoefgen, R.; Fernie, A.R. Shikimate and phenylalanine biosynthesis in the green lineage. Front. Plant Sci. 2013, 4, 62. [CrossRef]

62. Hildebrandt, T.M. Synthesis versus degradation: Directions of amino acid metabolism during Arabidopsis abiotic stress response. Plant Mol. Biol. 2018, 98, 121-135. [CrossRef]

63. Szecowka, M.; Heise, R.; Tohge, T.; Nunes-Nesi, A.; Vosloh, D.; Huege, J.; Feil, R.; Lunn, J.; Nikoloski, Z.; Stitt, M.; et al. Metabolic fluxes in an illuminated Arabidopsis rosette. Plant Cell 2013, 25, 694-714. [CrossRef]

64. Arrivault, S.; Obata, T.; Szecówka, M.; Mengin, V.; Guenther, M.; Hoehne, M.; Fernie, A.R.; Stitt, M. Metabolite pools and carbon flow during $\mathrm{C} 4$ photosynthesis in maize: ${ }^{13} \mathrm{CO}_{2}$ labeling kinetics and cell type fractionation. J. Exp. Bot. 2017, 68, 283-298. [CrossRef]

65. Obata, T.; Fernie, A.R. The use of metabolomics to dissect plant responses to abiotic stresses. Cell. Mol. Life Sci. 2012, 69, 3225-3243. [CrossRef] 
66. Mata, A.T.; Jorge, T.F.; Pires, M.V.; António, C. Drought stress tolerance in plants: Insights from metabolomics. In Drought Stress Tolerance in Plants, Molecular and Genetic Perspectives; Hossain, M.A., Wani, S.H., Bhattachajee, S., Burritt, D.J., Phan, L.S., Eds.; Springer International Publishing: Cham, Switzerland, 2016; Volume 2, pp. 187-216. [CrossRef]

67. Li, Z.; Yu, J.; Peng, Y.; Huang, B. Metabolic pathways regulated by $\gamma$-aminobutyric acid (GABA) contributing to heat tolerance in creeping bentgrass (Agrostis stolonifera). Sci. Rep. 2016, 6, 30338. [CrossRef]

68. Fait, A.; Fromm, H.; Walter, D.; Galili, G.; Fernie, A.R. Highway or byway: The metabolic role of the GABA shunt in plants. Trends Plant Sci. 2008, 13, 14-19. [CrossRef]

69. António, C.; Päpke, C.; Rocha, M.; Diab, H.; Limami, A.M.; Obata, T.; Fernie, A.R.; van Dongen, J.T. Regulation of primary metabolism in response to low oxygen availability as revealed by carbon and nitrogen isotope redistribution. Plant Physiol. 2016, 170, 43-56. [CrossRef] [PubMed]

70. Szabados, L.; Savoure, A. Proline: A multifunctional amino acid. Trends Plant Sci. 2010, 15, 89-97. [CrossRef]

71. Liang, X.; Zhang, L.; Natarajan, S.K.; Becker, D.F. Proline mechanisms of stress survival. Antioxid. Redox Signal. 2013, 19, 998-1011. [CrossRef]

72. Kaur, G.; Asthir, B. Proline: A key player in plant abiotic stress tolerance. Biol. Plant 2015, 59, 609-619. [CrossRef]

73. Per, T.S.; Khan, N.A.; Reddy, P.S.; Masood, A.; Hasanuzzaman, M.; Khan, M.I.R.; Anjum, N.A. Approaches in modulating proline metabolism in plants for salt and drought stress tolerance: Phytohormones, mineral nutrients and transgenics. Plant Physiol. Biochem. 2017, 115, 126-140. [CrossRef]

74. Sellstedt, A.; Atkins, C.A. Composition of amino compounds transported in xylem of Casuarina sp. J. Exp. Bot. 1991, 42, 1493-1497. [CrossRef]

75. Galili, G. The aspartate-family pathway of plants: Linking production of essential amino acids with energy and stress regulation. Plant Signal. Behav. 2011, 6, 192-195. [CrossRef]

76. Bailey-Serres, J.; Mittler, R. The roles of reactive oxygen species in plant cells. Plant Physiol. 2006, 141, 311. [CrossRef]

77. Blokhina, O.; Vironlainen, E.; Fagerstedt, K.V. Antioxidants, oxidative damage and oxygen deprivation stress: A review. Ann. Bot. 2003, 91, 179-194. [CrossRef]

78. Foyer, C.H.; Shigeoka, S. Understanding oxidative stress and antioxidant functions to enhance photosynthesis. Plant Physiol. 2011, 155, 93-100. [CrossRef] [PubMed]

79. Agati, G.; Azzarello, E.; Pollastri, S.; Tattini, M. Flavonoids as antioxidants in plants: Location and functional significance. Plant Sci. 2012, 196, 67-76. [CrossRef] [PubMed]

80. Tromas, A.; Parizot, B.; Diagne, N.; Champion, A.; Hocher, V.; Cissoko, M.; Crabos, A.; Prodjinoto, H.; Lahouze, B.; Bogusz, D.; et al. Heart of endosymbioses: Transcriptomics reveals a conserved genetic program among arbuscular mycorrhizal, actinorhizal and legume-rhizobial symbioses. PLoS ONE 2012, 7, e44742. [CrossRef]

81. Zhong, C.; Zhang, Y.; Chen, Y.; Jiang, Q.; Chen, Z.; Liang, J.; Pinyopusarerk, K.; Franche, C.; Bogusz, D. Casuarina research and applications in China. Symbiosis 2010, 50, 107-114. [CrossRef]

82. Ramalho, J.C.; Rodrigues, A.P.; Lidon, F.; Marques, L.M.C.; Leitão, A.E.; Fortunato, A.S.; Pais, I.P.; Silva, M.J.; Scotti-Campos, P.; Lopes, A.; et al. Stress cross-response of the antioxidative system promoted by superimposed drought and cold conditions in Coffea spp. PLoS ONE 2018, 13, e0198694. [CrossRef]

83. Schreiber, U. Pulse-amplitude-modulation (PAM) fluorometry and saturation pulse method: An overview. In Chlorophyll a Fluorescence: A Signature of Photosynthesis; Papageorgiou, G.C., Ed.; Springer: Dordrecht, The Netherlands, 2004; pp. 279-319. [CrossRef]

84. Klughammer, C.; Schreiber, U. Complementary PS II quantum yields calculated from simple fluorescence parameters measured by PAM fluorometry and the saturation pulse method. PAM Appl. Notes 2008, 1, 27-35.

85. Ramalho, J.C.; Pons, T.L.; Groeneveld, H.W.; Nunes, M.A. Photosynthetic responses of Coffea arabica leaves to a short-term high light exposure in relation to N availability. Physiol. Plant 1997, 101, 229-239. [CrossRef]

86. Ramalho, J.C.; Rodrigues, A.P.; Semedo, J.N.; Pais, I.P.; Martins, L.D.; Simões-Costa, M.C.; Leitão, A.E.; Fortunato, A.S.; BatistaSantos, P.; Palos, I.M.; et al. Sustained photosynthetic performance of Coffea spp. under long-term enhanced [CO 2$]$. PLoS ONE 2013, 8, e82712. [CrossRef] [PubMed]

87. Matos, M.C.; Campos, P.S.; Passarinho, J.A.; Semedo, J.N.; Marques, N.M.; Ramalho, J.C.; Ricardo, C.P. Drought effect on photosynthetic activity, osmolyte accumulation and membrane integrity of two Cicer arietinum genotypes. Photosynthetica 2010, 48, 303-312. [CrossRef]

88. Campos, P.S.; Quartin, V.L.; Ramalho, J.C.; Nunes, M.A. Electrolyte leakage and lipid degradation account for cold sensitivity in leaves of Coffea sp. plants. J. Plant Physiol. 2003, 160, 283-292. [CrossRef]

89. Beauchamp, C.; Fridovich, I. Superoxide dismutase: Improved assay and an assay applicable to acrylamide gels. Anal. Biochem. 1971, 44, 276-287. [CrossRef]

90. Esterbauer, H.; Grill, D. Seasonal variation of glutathione and glutathione reductase in needles of Picea abies. Plant Physiol. 1978, 61, 119-121. [CrossRef] [PubMed]

91. Kato, M.; Shimizu, S. Chlorophyll metabolism in higher plants. VII. Chlorophyll degradation in senescing tobacco leaves; phenolic-dependent peroxidative degradation. Can. J. Bot. 1987, 65, 729-735. [CrossRef]

92. Ramalho, J.C.; Campos, P.S.; Teixeira, M.; Nunes, M.A. Nitrogen dependent changes in antioxidant systems and in fatty acid composition of chloroplast membranes from Coffea arabica L. plants submitted to high irradiance. Plant Sci. 1998, 135, 115-124. [CrossRef] 
93. Lisec, J.; Schauer, N.; Kopka, J.; Willmitzer, L.; Fernie, A.R. Gas chromatography mass spectrometry-based metabolite profiling in plants. Nat. Protoc. 2006, 1, 387-396. [CrossRef]

94. Luedemann, A.; Strassburg, K.; Erban, A.; Kopka, J. TagFinder for the quantitative analysis of gas chromatography-mass spectrometry (GC-MS)-based metabolite profiling experiments. Bioinformatics 2008, 24, 732-737. [CrossRef]

95. Kopka, J.; Schauer, N.; Krueger, S.; Birkemeyer, C.; Usadel, B.; Bergmüller, E.; Dörmann, P.; Weckwerth, W.; Gibon, Y.; Stitt, M.; et al. Gmd@csb.Db: The Golm Metabolome Database. Bioinformatics 2005, 21, 1635-1638. [CrossRef] [PubMed]

96. Alseekh, A.; Aharoni, A.; Brotman, Y.; Contrepois, K.; D’Auria, J.; Ewald, J.; Ewald, J.C.; Fraser, P.D.; Giavalisco, P.; Hall, R.D.; et al. Mass spectrometry-based metabolomics: A guide for annotation, quantification and best reporting practices. Nat. Methods 2021, 18, 747-756. [CrossRef]

97. Tohge, T.; Fernie, A.R. Combining genetic diversity, informatics and metabolomics to facilitate annotation of plant gene function. Nat. Protoc. 2010, 5, 1210-1227. [CrossRef]

98. Guijas, C.; Montenegro-Burke, J.R.; Domingo-Almenara, X.; Palermo, A.; Warth, B.; Hermann, G.; Koellensperger, G.; Huan, T.; Uritboonthai, W.; Aisporna, A.E.; et al. METLIN: A technology platform for identifying knowns and unknowns. Anal. Chem. 2018, 90, 3156-3164. [CrossRef] [PubMed]

99. R Core Team. R: A Language and Environment for Statistical Computing; R Package v.3.4.3; R Foundation for Statistical Computing: Vienna, Austria, 2018; Available online: https:/ / www.R-project.org/ (accessed on 12 December 2019).

100. Raivo, K. Pheatmap: Pretty Heatmaps. R Package v.1.0.8. 2015. Available online: https://CRAN.R-project.org/package= pheatmap (accessed on 12 December 2019).

101. Rohart, F.; Gautier, B.; Singh, A.; Cao, K.A.L. mixOmics: An R package for 'omics feature selection and multiple data integration. PLoS Comput. Biol. 2017, 13, e1005752. [CrossRef]

102. Chen, H.; Boutros, P.C. VennDiagram: A package for the generation of highly-customizable Venn and Euler diagrams in R. BMC Bioinformat. 2011, 26, 12-35. [CrossRef]

103. Werner, C.; Correia, O.; Beyschlag, W. Characteristic patterns of chronic and dynamic photoinhibition of different functional groups in a Mediterranean ecosystem. Funct. Plant Biol. 2002, 29, 999-1011. [CrossRef] [PubMed]

104. Fiehn, O.; Sumner, L.W.; Rhee, S.Y.; Ward, J.; Dickerson, J.; Lange, B.M.; Lane, G.; Roessner, U.; Last, R.; Nikolau, B. Minimum reporting standards for plant biology context in metabolomics studies. Metabolomics 2007, 3, 195-201. [CrossRef]

105. Sumner, L.W.; Amberg, A.; Barrett, D.; Beale, M.H.; Beger, R.; Daykin, C.A.; Fan, T.W.M.; Fiehn, O.; Goodacre, R.; Griffin, J.L.; et al. Proposed minimum reporting standards for chemical analysis. Metabolomics 2007, 3, 211-221. [CrossRef] [PubMed]

106. Fernie, A.R.; Aharoni, A.; Willmitzer, L.; Stitt, M.; Tohge, T.; Kopka, J.; Carroll, A.J.; Saito, K.; Fraser, P.D.; De Luca, V. Recommendations for reporting metabolite data. Plant Cell 2011, 2, 2477-2482. [CrossRef] 